\title{
Bilirubin and red cell metabolism in relation to neonatal jaundice
}

\author{
Timos VAlaes \\ M.D. (Bristol) D.C.H. \\ The 'Queen Anna-Maria' Institute of Child Health, Athens, Greece
}

\section{Introduction}

For over half a century neonatal jaundice has been the subject of clinical and laboratory investigations. Spectacular progress has been made during these years. Work on neonatal jaundice has contributed to our understanding of physiological and pathological mechanisms in the areas of foeto-maternal relationships, of bile pigment biochemistry and metabolism, etc. Notwithstanding these fundamental contributions the exact mechanism of even the most common type of neonatal jaundice, the so-called 'physiological jaundice', is still beyond our grasp. Moreover, in recent years disturbances of red-cell metabolism have been recognized as important causes of severe neonatal jaundice in some ethnic groups, while racial and geographical differences in the degree of non-specific neonatal hyperbilirubinaemia have added to the complexity of the subject. These latter aspects of neonatal jaundice are the main subject of the present review.

To identify some areas relevant to our main discussion a brief outline of bilirubin metabolism in the newborn follows. For more details the reader is referred to many excellent recent reviews (Billing \& Lathe, 1958; Lathe, Claireaux \& Norman, 1958; Lucey, 1960; Zuelzer \& Brown, 1961 ; Brown, 1962; Lester \& Schmid, 1964; Cracco, Dower \& Harris, 1965).

\section{Metabolism of bilirubin in the newborn Bilirubin production}

Jaundice always means that the production of bilirubin exceeds excretion with the result that the pigment accumulates in the plasma and the tissues. Bilirubin production basically means red-cell destruction-haemolysis - either at the end of their normal life or at an earlier stage through a variety of mechanisms which shorten red-cell life-span. A small proportion of the daily production of bilirubin is not derived from the degradation of haemoglobin liberated from mature red cells but from other sources (Gray, Newberger \& Sneath, 1950; London et al., 1950). In the adult the amount of bilirubin derived from sources other than the break-down of red cells is approximately $10-15 \%$ of the total, while in the newborn period this amount is in full-term infants $21-25 \%$, and in prematures $30 \%$ of the total bilirubin load (Vest, 1967). In assessing the daily load of bilirubin in the newborn period two more factors should be considered: (a) The infant begins its life with an increased concentration and total mass of haemoglobin per $\mathrm{kg}$ of body weight; and (b) the life-span of the red cells of the newborn (term, and particularly of the pre-term one) is shortened (80 days approximately) compared with that of the adult (120 days) (Vest \& Grieder, 1961; Kaplan \& Hsu, 1961; Garby, Sjolin \& Viulle, 1964; Pearson, 1967; Maisels, Pathak \& Nelson, 1968).

\section{Bilirubin excretion}

Three steps have been recognized in bilirubix excretion: (a) uptake of bilirubin by the liver cells (b) conjugation of bilirubin with glucuronic acid to form a diglucuronide ester of bilirubin; and (c) excretion of conjugated bilirubin by the liver cells into the lumen of biliary canaliculi.

The first step has not been studied in newborn animals. In mature animals it is not the rate-limiting step (Grodsky, 1967). Conjugation of bilirubin takes place mainly in the liver. Uridine diphosphoglucuronic acid is the donor substance and the enzyme glucuronyl transferase catalyses the transfer of glucuronic acid to bilirubin (Grodsky \& Carbone, 1957; Lathe \& Walker, 1957; Schmid, Hammaker \& Axelrod, 1957). It is now accepted that the newborn period is characterized by a relative insufficiency of the enzymatic mechanism of bilirubin conjugation (Lathe \& Walker, 1957; Brown \& Burnett, 1957; Brown, Zuelzer \& Burnett, 1958; Dutton, 1958, 1959; Vest, 1958). This functional immaturity of the liver of the newborn is more pronounced in infants with shortened gestation. The degree of this insufficiency is not amenable to direct measurement but there is indirect evidence of a considerable individual variation. This can be exemplified by the number of infants with haemolytic disease of the newborn (HDN) from Rhesus incompatibility who develop severe anaemia with little or no jaundice and by the variable degree of hyperbilirubinaemia in infants with similar extravasation 
of blood in cases of giant subaponeurotic cephalhaematomas (Valaes \& Doxiadis, 1968). It has been estimated that it takes approximately $3-4$ weeks for the mature infant to reach adult levels of bilirubinconjugating capacity (Vest, 1958). The availability of the donor substance uridine diphosphate glucuronic acid depends on a complex enzymatic process which includes carbohydrate metabolism and a specific enzyme of the soluble fraction of the liver homogenate, UDPGA dehydrogenase, which again is diminished in the neonatal period (Brown et al., 1958; Dutton, 1958, 1959).

The enzymatic insufficiency, which leads to decreased capacity for bilirubin excretion and to the accumulation of indirect, lipid-soluble, bilirubin, is the common denominator of all types of neonatal jaundice whatever are the other co-existing mechanisms. This transient metabolic immaturity of the newborn explains many of the clinical peculiarities of neonatal jaundice.

The final phase in bilirubin excretion, i.e. the excretion of conjugated bilirubin by the liver cells into the biliary canaliculi, is not yet fully understood (Lester \& Schmid, 1964). Work by Arias, Johnson \& Wolfson (1961) has suggested that this step is a rate-limiting one in bilirubin excretion in the adult rat. In foetal guinea-pigs Schenker and his associates (Schenker, Dawber \& Schmid, 1964) found impaired excretion of conjugated bilirubin suggesting that this step is also immature in the newborn period. There is indirect evidence that this applies also to human newborns. The most plausible explanation for the appearance of high conjugated bilirubin values in the course of haemolysis in the newborn period-the so called inspissated bile syndrome-is a discrepancy between conjugating and excretory capacity in the course of the maturation of the liver (Lester \& Schmid, 1964). Thus in almost all the cases where severe haemolysis occurred or continued at the end or after the 1st week of life (in cases of G-6-PD deficiency, pyknocytosis with or without G-6-PD deficiency and naphthalene inhalation) (Valaes, Doxiadis \& Fessas, 1963; and personal material) high values of conjugated bilirubin were observed with no other evidence of obstruction to the bile flow. Thus it appears that at the end of the 1st week of life and approximately till the end of the 1st month, at least under the influence of high bilirubin loads (and serum bilirubin concentrations) the conjugating capacity of the liver increases more rapidly than its excretory ability for bilirubin. Bakken \& Fog (1967a) explained the appearance of conjugated bilirubin in the serum of normal newborns on the 2 nd to 3 rd days and its decrease after the 6th to 7 th days on the same principle of phase difference between the maturation of the conjugating and excretory systems. It should be noted that the time-interval was not connected with the maturity of the infant and seemed to be conditioned only by the onset of extrauterine existence.

\section{Significance of defective foetal bilirubin conjugation}

Teleologically speaking we can say that the insufficiency of conjugation is an advantage to the foetus as it leads to the removal of the bilirubin produced during foetal life by the maternal liver. Experimental work has shown that unconjugatedlipid-soluble-bilirubin easily crosses the placental membrane and enters the maternal circulation even at a very low gradient (Lester, Behrman \& Lucey, 1963; Wynn, 1963; Grodsky et al., 1963; Schenker, Bushare \& Smith, 1967) while conjugated bilirubin enters the maternal side only in very small amounts (Schenker et al., 1967). Even before this experimental evidence, disposal of foetal bilirubin through the maternal liver was postulated in order to explain the relatively low concentration of serum bilirubin in the cord blood of infants with HDN.

An alternative and more plausible explanation for the low bilirubin-conjugating capacity of the newborn would be that the placental circulation by removing the bilirubin produced in foetal life removes the stimulus for the development of the conjugating mechanism which then should be considered one of the adaptive enzymatic systems (Sereni \& Principi, 1965). That this might be true is suggested by a close quantitative study of the bilirubin metabolism in cases of severe HDN from Rhesus isoimmunization. The fairly good correlation between cord-blood serum bilirubin values and the severity of the haemolytic process suggest that in spite of the readiness with which bilirubin crosses the placenta, when the load of bilirubin increases, for effective transfer across the placenta to the maternal circulation the gradient must increase correspondingly. Thus in cases of severe HDN and particularly in the cases maintained alive, in spite of very rapid haemolysis, through intrauterine transfusions, relatively high serum-bilirubin values exist in intrauterine life. These infants are known to be born with high conjugated bilirubin values in the cord-blood and go on to show the so-called 'inspissated bile syndrome'. In such a case it was possible to estimate the conjugation of bilirubin in the first few days of life. It was found that it exceeded, in relation to weight, six times the normal amount excreted by an adult (Valaes, 1963; Maisels et al., 1968).

Thus as noted by Bakken \& Fog (1967a), we can say that in HDN the high bilirubin values existing in intrauterine life trigger the maturation of the conjugating system and what usually happens after the onset of extrauterine life in these infants shifts to the prenatal period. 
Simulating these conditions Bakken \& Fog (1967b) demonstrated that the bilirubin-glucuronyl transferase activity of the liver of newborn rats was increased if the mothers were loaded with bilirubin shortly before delivery. These observations strengthen the attempts to stimulate the development of the glucuronidation system by substances given to the mother or the newborn infant. Such substances that gave promising results in animal experiments include 3, 4-benzpyrene (Inscoe \& Axelrod, 1960); phenobarbitone and nikethamide (Careddu et al., 1964; Kato, Loeb \& Gelboin, 1965). Evidence is already accumulating that phenobarbitone is effective in promoting the conjugating capacity of the liver in human newborns and thus decreases the degree of neonatal hyperbilirubinaemia (Crigler \& Gold, 1966; Yaffé et al., 1966; Trolle 1968; Khanna et al., 1968; Maurer et al., 1968).

On the other side other hepatic conjugating systems such as $\mathrm{N}$-acetyl-transferase have diminished activity during foetal life with no evidence that this might be an advantage or that maturation is substrate dependent (Weber \& Cohen, 1968). There is some evidence that in this enzyme system (Weber \& Cohen, 1968) as well as in glucuronyl transferase, maturation is connected with a switch from a foetal form of the enzyme to the adult one (Krasner \& Yaffé, 1968).

In any case the factors that bring about the maturation of the enzyme systems are not only of theoretical but also of immense practical interest as the speeding up of the maturation process constitutes the simplest solution to most of the therapeutic problems posed by neonatal hyperbilirubinaemia.

\section{Inhibition of conjugation}

In considering the bilirubin-conjugating capacity of the newborn in the last few years it became apparent that another factor ought to be taken into account. The serum of women at term as well as the serum of the newborn infants contains a substance which can inhibit in an in vitro system the conjugation of bilirubin (Lathe \& Walker, 1958; Waters, Dunham \& Bowen, 1958; Hsia et al., 1960).

This inhibitory effect could be demonstrated in the breast milk of some women whose infants showed prolonged mild hyperbilirubinaemia-'breast-milk jaundice' (Katz \& Robinson, 1965; Stiehm \& Ryan, 1965; Rösta \& Szöke, 1965; Gartner \& Arias, 1966). Similarly greatly elevated inhibitory activity was detected in the serum of some mothers whose infants showed marked unexplained hyperbilirubinaemia (Arias et al., 1965). This inhibitory effect in the serum or the breast milk is connected with progestational agents (Newman \& Gross, 1963; Gartner \& Arias, 1964; Arias et al., 1964).

\section{Neonatal jaundice: a problem with many unknowns}

From the above discussion it follows that in every case of neonatal jaundice we should consider the contribution made by three separate factors: (a) production of bilirubin, (b) insufficient conjugatory capacity, and (c) inhibition of conjugation. The interrelationship between these factors can be expressed as follows:

(a) Degree of hyperbilirubinaemia = bilirubin production - bilirubin excretion.

(b) Bilirubin excretion = conjugating capacity inhibition of conjugation.*

(c) Degree of hyperbilirubinaemia = bilirubin production - (conjugatory capacity - inhibition of conjugation).

Each one of the three factors can vary independently of the other two in individual cases and of moreover the relative importance of each factor can change rapidly in the first few days of life. At present neither bilirubin production nor conjugating capacity and inhibition can be measured accurately on a practical basis. This explains why neonatal jaundice is always a problem with many unknown variants even when the main mechanism is known. For the sake of simplicity, it has been usual to classify neonatal jaundice by stressing the most important factor in each group of cases. Thus we can separate the cases of neonatal jaundice in three main groups: (a) those in which an increased bilirubin proe duction is the main factor, (b) those with a much decreased conjugatory capacity, and (c) those in which inhibition of conjugation is the predominant factor. This classification is depicted graphically in Fig. 1. It is obvious that within each group differences in the degree of hyperbilirubinaemia between the individual cases can be due to variation in each of the three factors. This is also true for the so-called 'physiological jaundice'.

The above, rather complicated, picture should not obscure the fact that, had the newborn been endowed with a bilirubin excretory capacity anything near the adult level, there would not be problems in neonatal jaundice. It is the absence of reserves in the excretory capacity that gives importance even to small changes in bilirubin production or in inhibition. In that sense the neonatal period is the most sensitive one for the clinical manifestation of degrees of haemolysis which in other periods remain clinically silent (Valaes, 1961).

Outside the neonatal period the rate of red-cell destruction must increase two- to three-fold to be of any consequence and usually the result is a com-

* To simplify and stress the steps of practical importance in this formula the phase of the excretion of conjugated bilirubin has been omitted. Similarly the enterohepatic circulation of bilirubin, although it might prove of considerable importance in the neonatal period, is not considered. 


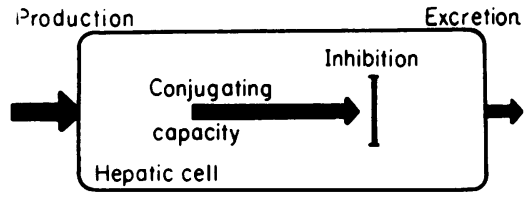

(a)

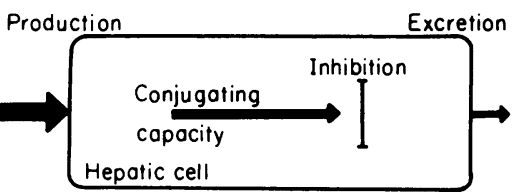

(c)

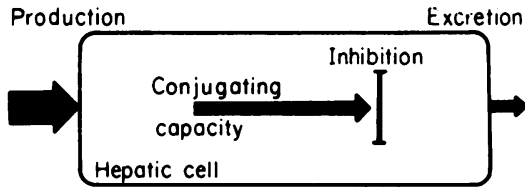

(b)

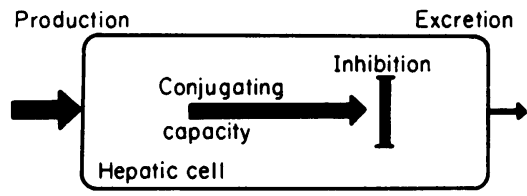

(d)

FIG. 1. Basic mechanisms of neonatal jaundice. (a) 'Physiological' jaundice, (b) haemolytic jaundice, (c) jaundice from insufficient conjugation, and (d) jaundice from increased inhibition.

pensated haemolytic syndrome with no anaemia or jaundice. Under similar conditions in the neonatal period the increase of the bilirubin load two- or three-fold may result in severe jaundice and kernicterus. Thus in cases of severe jaundice in the newborn period the concentration of haemoglobin cannot be used as a criterion of haemolysis. It has been estimated, on the basis of the total bilirubinspace and the total mass of haemoglobin of the newborn, that an increase of serum bilirubin concentration exceeding 5-6 mg/24 hr cannot be accounted for solely by defective bilirubin excretion and indicates increased haemolysis (Valaes, 1963).

In Table 1 an aetiological classification of neonatal jaundice is attempted excluding conditions with an obstructive element and high conjugated bilirubin values. From the conditions listed in Table 1 only the ones related to the newly opened field of abnormalities of the red-cell glucose metabolism will be discussed.

Neonatal jaundice connected with defects in the pathways of glucose metabolism of the red cell

\section{Introduction}

The mature red cell is a highly specialized cell which has evolved to perform the important function of oxygen transport. It is a cell which, although endowed with limited metabolic capacities, can fulfil its purpose with a minimum oxygen consumption and energy expenditure.

To remain viable the red cell must maintain its volume, bi-concave shape and plasticity in the face of an osmotic and electrochemical gradient and constant wear-and-tear while passing through the narrow capillaries. The red cell needs also to generate an oxidation-reduction potential in order to be able to protect haemoglobin from being oxidized to methaemoglobin and to protect the other enzymes and the membrane from oxidative degradation. These requirements are met through the metabolism of glucose (Fig. 2) which provides both energy and compounds with redox potential. Energy is generated mainly in the form of adenosine triphosphate (ATP) in the Embden-Meyerhof anaerobic glycolytic pathway and is required to operate the sodium and potassium pump. Reduced nicotinamide adenine dinucleotide (NADH, or reduced diphosphopyridine nucleotide, DPNH) is an essential co-factor of the anaerobic pathway and is also responsible for the reduction of methaemoblobin constantly generated in the red cell.

The pentose-phosphate pathway (PPP) of oxidative glycolysis, although under usual condition involving only approximately $10 \%$ of the metabolism of glucose, is of great importance. This cycle maintains glutathione in the reduced state through the generation of reduced nicotinamide adenine dinucleotide phosphate (NADPH, or reduced triphosphopyridine nucleotide, TPNH). Under oxidant stress this pathway can be stimulated many-fold the normal rate and this permits the red cell to maintain its viability in the presence of oxidant substances either exogenous or endogenous (i.e. ascorbic acid, cysteine). Reduced glutathione is important for the protection of the sulphydryl groups of the haemoglobin, of the red cell enzymes and of the membrane, and thus is an all-essential compound for the survival of the red cell.

A detailed account of red-cell metabolism is beyond the scope of this work and the reader is referred to many recent reviews and monographs (Prankerd, 1961, 1965; Carson \& Tarlov, 1962; Harris, 1963; Jandl, 1966; Hoffman, 1966; Carson \& Frischer, 1966; Keitt, 1966). Red-cell age is of great importance to metabolism. The pattern of enzyme activity and the metabolic rate are closely related to the age (Marks, Johnson \& Hirschberg, 1958). The 
TABLE 1. Aetiological classification of neonatal jaundice (of the non-obstructive type)

Hyperbilirubinaemia in the newborn from increased bilirubin production

(A) With no increase in the rate of haemolysis

(1) High total haemoglobin mass (intrauterine hypoxia, syndrome of intrauterine transfusion in uniovular twins, maternofoetal transfusion)

(2) Liberation of haemoglobin from extravasated red cells (extensive bruising, giant sub-aponeurotic cephalhaematoma)

(B) With increased rate of haemolysis

(1) Isoimmunization (Rhesus, ABO, other blood groups)

(2) Metabolic defects of the red cells

(a) Non-specific (in all newborns and more so in the pre-term)

(b) Specific defects in the glycolytic enzymes:

(i) Of the anaerobic pathway (Embden-Meyerhof)

Pyruvate kinase deficiency

Triosephosphate isomerase deficiency

2,3-Diphosphoglycerate mutase deficiency

Hexokinase deficiency

(Glucosephosphate isomerase deficiency)*

(ii) Of the oxidative pentose phosphate pathway

Glucose-6-phosphate dehydrogenase deficiency

6-Phosphogluconate dehydrogenase deficiency

(Glutathione reductase deficiency)*

(c) Other enzyme and metabolite defects

Glutathione peroxidase deficiency

(Adenosine triphosphatase deficiency)*

(Catalase deficiency-acatalasia)*

(Congenital absence of reduced glutathione)*

(d) Red cell membrane defects

Hereditary spherocytosis

Elliptocytosis

Stomatocytosis

K.K. disease

(High sodium-low potassium disease)*

(e) Haemoglobinopathies

Hydrops foetalis in homozygous a-Thalassaemia

Congenital haemolytic anaemia with unstable haemoglobins

(3) Injury by drugs

Anaemia with Heinz-bodies (Vitamin $\mathrm{K}$ analogues, naphthalene intoxication, etc.)

Infantile pyknocytosis (some cases)

(4) Infections

Bacterial (E.coli)

Viral (cytomegalic inclusions, neonatal hepatitis)

Toxoplasmosis

Syphilis

Hyperbilirubinaemia in the newborn from deficient conjugating capacity

(A) Present in all types of neonatal jaundice as a common factor

(B) Marked deficiency playing a primary role in the jaundice of:

(1) Pre-term infants

(2) Congenital hypothyroidism

(C) Congenital hereditary deficiency of the enzyme glucuronyl transferase Crigler-Najjar disease

Hyperbilirubinaemia in the newborn from inhibition of bilirubin conjugation

(A) Naturally occurring inhibiting substances:

(a) In the serum of pregnant women

(b) In the breast milk of some women

(1) Probably contributes to all types of neonatal jaundice

(2) Prolonged jaundice of the breast-fed infants

(3) 'Transient familial non-haemolytic neonatal hyperbilirubinaemia'

(B) Inhibition due to drugs

Novobiocin

Miscellaneous and unclassifiable

(A) Increased hyperbilirubinaemia in some clinical conditions

(a) Infants of diabetic mothers

(b) Infants with Down's syndrome

(c) Infants with intestinal obstruction

(B) Increased hyperbilirubinaemia in some racial or geographical groups

* Not yet described as a cause of neonatal jaundice. 


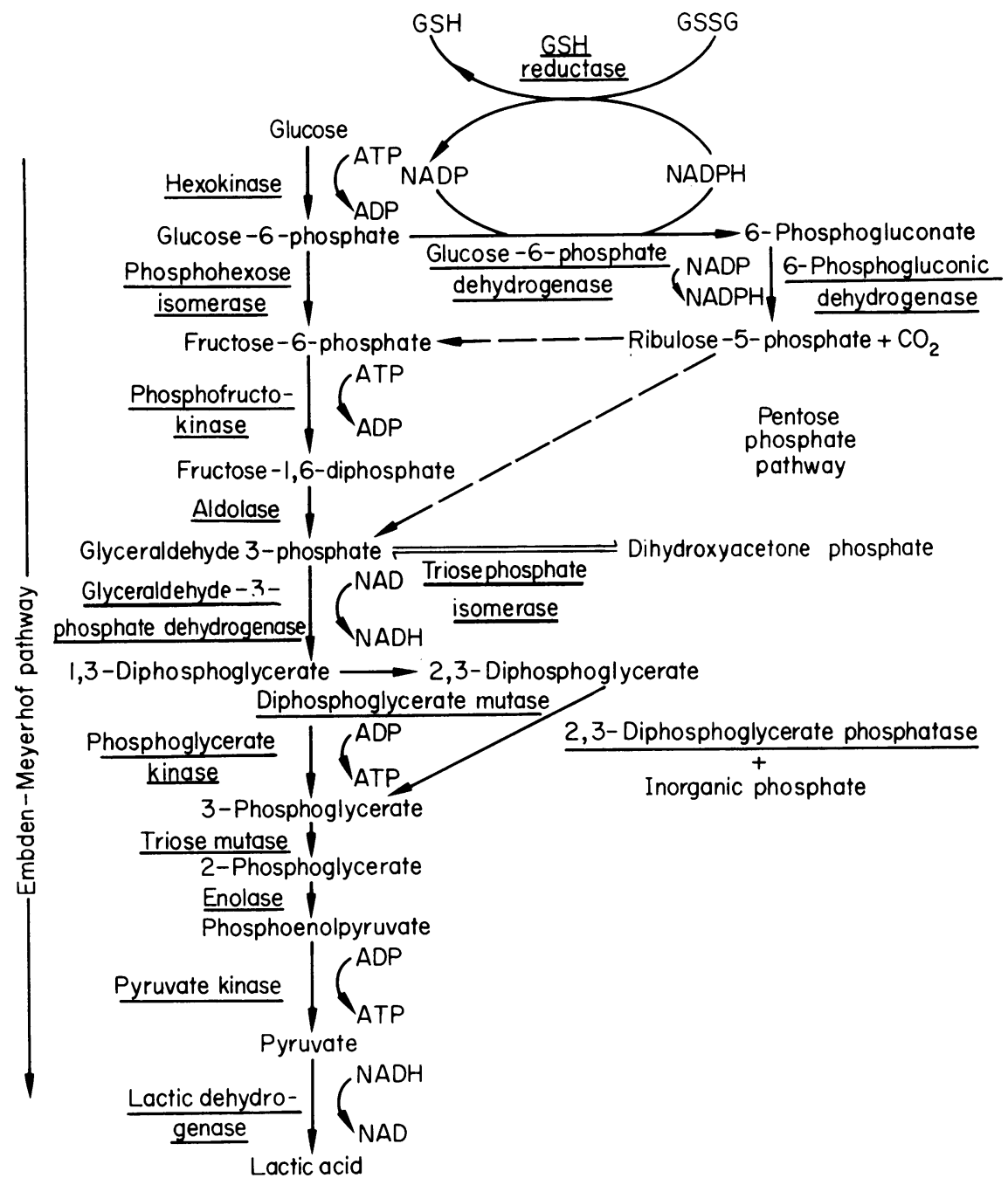

FIG. 2. Metabolism of glucose.

failure of the red cell to maintain its energy requirements, through degradation of rate-limiting enzymes of the glycolytic pathway, is the cause of its limited life-span. Studying a metabolic parameter in a blood sample we only measure the mean value of a heterogeneous population which includes all the range between the very young and the very old cells. Sometimes measurements of enzyme activity, or even more important, clinical manifestations can be altered by a change in the mean red-cell age. An example of this can be found in the newborn period. As a result of the shortened life-span of foetal red cells and the rapid expansion of total red-cell mass during the rapid growth of the last trimester of pregnancy the mean red-cell age at birth is much lower. Some of the metabolic peculiarities of the erythrocytes in the newborn period can be explained on the basis of younger mean age of the red-cell population including increased enzyme activity (hexokinase, glyceraldehyde-3-phosphate dehydrogenase, pyruvate kinase, glucose - 6-phosphate dehydrogenase, 6-phosphogluconic dehydrogenase), increased glucose consumption and increased ATP content (Gross et al., 1963). The shortened life-span of the red cells of the newborn, increased mechanical fragility, increased vulnerability to oxidative stress with methaemoglobin accumulation and denaturation of haemoglobin in the form of Heinz-bodies and greater tendency to form 'spickled' red-cell forms on incubation, demonstrate the metabolically precarious state of the erythrocytes in the newborn period (Oski and 
Naiman, 1965; Oski, 1967).

The normal activity and response to stimulation of the PPP of the erythrocytes in the newborn period indicates that failure of this pathway is not responsible for their vulnerability to oxidant stress (Oski, 1967). The low activity of the erythrocytes of the newborn in catalase, glutathione peroxidase and NAD-dependent methaemoglobin reductase (diaphorase is a likely explanation for this vulnerability (Bracci et al., 1965; Gross et al., 1967). The erythrocytes of the newborn are also characterized by glutathione instability (Zinkham, 1959; Oski \& Naiman, 1965), ATP-increase without relative increase in ADP (Gross et al., 1963) and ATPinstability.

\section{General remarks on red cell enzymopathies}

Enzyme variants leading to defective enzyme activity have been described for almost all the enzymes involved in the two pathways of glucose metabolism of the erythrocyte. These enzymopathies have manifested clinically either as congenital non-spherocytic haemolytic anaemia (CNHA) or as haemolysis following exposure to exogenous agents, particularly primaquine and fava beans and finally as severe neonatal jaundice. The drug-induced haemolysis is connected with defective function of the PPP, while CNHA can result from defects in either the Embden-Meyerhof pathway or PPP.

The defects which produce CNHA have one thing in common, they are very rare. This is not a false impression created by the relatively recent development of the laboratory methods for their detection. The clinical condition described as CNHA (Dacie et $a l ., 1953$ ) is itself very rare (de Gruchy et al., 1960). The importance of these rare defects lies in the fact that through the study of such 'experiments of nature' our knowledge of red-cell metabolism is enlarged.

Glucose-6-phosphate dehydrogenase (G-6-PD) deficiency, the first enzyme defect to be described (Carson et al., 1956) is much commoner. It has been estimated that over 100 million people are affected (Carson, 1960). In many populations high frequencies of the G-6-PD deficiency gene are prevailing thus constituting an important genetic polymorphism (Motulsky \& Campbell-Kraut, 1961; Marks, 1963; Motulsky, 1963). Glucose-6-PD is the only enzyme studied so far in detail both in its normal type and the abnormal variants. It can serve as a prototype for our understanding of the abnormal variants of other red-cell enzymes. The extensive studies of Yoshida and collaborators (Yoshida, 1966, 1968; Yoshida, Stamatoyannopoulos \& Motulsky, 1967 ) as well as previous studies (Carson, Schrier \& Kellermeyer, 1959; Kirkman, Riley \& Crowell, 1960; Kirkman \& Hendrickson, 1963; Kirkman, Schettini \& Pickard, 1964a; Kirkman et al., 1964b;
Marks, Szeinberg \& Banks, 1961; Kirkman, 1962) have proved that the variants so far studied were the result of a structural mutation leading to differences from the normal enzyme in one or more of its functional characteristics: rate of decay, specific activity per molecule of enzyme, substrate affinity and substrate specificity. In this respect it should be mentioned that assays of enzyme activities in vitro do not represent the conditions in vivo. The conditions of the assays are those of optimum substrate concentration and the activity is measured in the whole population of the red cells. Thus diminished affinity of the enzyme for the substrate or a speeding up of enzyme decay in older cells escape recognition. Special studies are required for the detection of variants which produce such alterations in the behaviour of an enzyme. Moreover structural variants of the enzyme molecule might be of no functional significance and only their electrophoretic or chromatographic behaviour distinguishes them from the normal.

Autosomal recessive transmission has been proved for most of the enzyme defects. The homozygous individuals are affected clinically while the heterozygous carriers are asymptomatic although there are a few exceptions to this rule. For most of the enzyme studies it appears that different loci are directing the formation of the same enzyme in different tissues. Thus in red-cell pyruvate kinase and hexokinase deficiency the white-cell enzymes are normal. G-6-PD differs from other enzymes in being sex-linked (Childs et al., 1958) and the same locus is responsible for the enzyme in probably all the tissues (Nitowsky et al., 1965; Lunder \& Gartler, 1965; Chan, Todd \& Wong, 1965; Justice et al., 1966; Yoshida, 1968).

In relation to neonatal jaundice red cell enzymopathies are of interest as severe hyperbilirubinaemia might be the first manifestation of CNHA and G-6-PD deficiency may manifest in the neonatal period with severe jaundice in some population groups. The whole subject has been recently reviewed (Oski, 1965).

Enzyme defects of the anaerobic glycolytic pathway (Embden-Meyerhof)

The anaerobic pathway of glycolysis is the main supplier of energy for the red cells and defective operation of this pathway greatly limits their lifespan. Accordingly in most of the cases severe jaundice was expected to occur in the neonatal period. Actually, in only a small proportion of the cases so far reported was neonatal jaundice conspicuous, while anaemia was obvious very early in infancy. It is possible that although an increased rate of haemolysis exists in the neonatal and intrauterine periods, these infants do not develop severe jaundice because 
TABle 2. Pyruvate kinase deficiency with manifestation in the neonatal period

\begin{tabular}{|c|c|c|c|c|c|}
\hline $\begin{array}{l}\text { Ethnic } \\
\text { origin }\end{array}$ & $\begin{array}{l}\text { Total } \\
\text { cases }\end{array}$ & $\begin{array}{l}\text { Cases with } \\
\text { icterus } \\
\text { neonatorum }\end{array}$ & $\begin{array}{l}\text { Exchange } \\
\text { transfusion }\end{array}$ & $\begin{array}{l}\text { Onset of } \\
\text { anaemia in } \\
\text { infancy }\end{array}$ & References \\
\hline \multicolumn{6}{|c|}{ Six North European, one } \\
\hline Mexican & 7 & 2 & 1 & 4 & Tanaka, Valentine \& Miwa (1962) \\
\hline North European & 3 & 2 & 1 & 2 & Oski \& Diamond (1963) \\
\hline French & 1 & - & - & 1 & Boivin \& Mallarmé (1963) \\
\hline Italian & 2 & $?$ & $?$ & 2 & Brunetti et al. (1963) \\
\hline German & 1 & $1(+2$ siblings $)$ & 1 & $\overline{1}$ & Busch (1963) and Busch et al. (1966) \\
\hline English & 1 & 1(Rhesus?) & 1 & 1 & Bowdler \& Prankerd (1964) \\
\hline North European & 1 & 1 & 1(Kernicterus?) & 1 & Oski et al. (1964) \\
\hline Italian & 1 & $?$ & - & 1 & Bestetti et al. (1964) \\
\hline Amish & 21 & $6+$ & 3(1 Kernicterus) & 21 & Bowmann et al. (1965) \\
\hline North European & 2 & $2(+1$ sibling $)$ & - & 2 & Keitt (1966) \\
\hline Italian & 1 & $1(+1$ sibling $)$ & $1(+1$ sibling $)$ & 1 & Volpato et al. (1968) \\
\hline Total & 41 & 16 & 9 & 37 & \\
\hline
\end{tabular}

of better than average bilirubin conjugation and excretion. Further discussion on this point must wait for more clinical and laboratory details on the natural course during the neonatal period of enzymopathies of the anaerobic pathway.

Pyruvate kinase (PK) deficiency is after G-6-PD deficiency the commonest enzyme defect found in cases of CNHA. More than eighty cases have been reported so far (for list of references see Keitt, 1966; Volpato, Vige \& Cattarozi, 1968). It is impossible to estimate the percentage of cases with neonatal manifestations, as in many of the reports no clinical details are given, or vague descriptions such as 'anaemia or icterus present since birth' make it difficult to form a clearcut picture of the neonatal course in this enzymomopathy. In Table 2 we have listed all the reports which include cases of PK deficiency with neonatal manifestations.

In approximately half of the cases severe neonatal jaundice and anaemia developed in the first few days of life. In a large proportion of these infants exchange transfusion was performed while kernicterus occurred in two infants. Generally speaking, in this enzyme defect homozygous individuals present with chronic haemolysis often with exacerbations in the course of infections, while their heterozygous parents or relatives are asymptomatic. Nevertheless, in at least three of the cases with early onset of severe haemolysis partial PK deficiency was present (Oski \& Diamond, 1963; Busch et al., 1966; Volpato et al., 1968). This is only one example of the poor correlation between severity of clinical manifestations and the deficiency in enzyme activity as assessed in vitro. The severity of manifestations seems to be more uniform if members of the same family are considered (Busch et al., 1966; Keitt, 1966; Volpato et al., 1968) or the siblings are all of common origin as are the cases in the Amish isolate described by Bowmann, McKusick \& Drowamrazu (1965). More detailed study of the enzyme in the affected individuals is required in order to see whether different pathological variants are involved. Differences in the enzyme structure, kinetics and stability similar to those described for G-6-PD may account for the clinical variability. Already CNHA has been described with normal PK activity, with the usual assay conditions, but with very much diminished substrate affinity (high $K_{m}$ constant) of the enzyme (Paglia et al., 1967; Sachs et al., 1967; Zarkowsky et al., 1968; Miller et al., 1968). The lack of uniformity in the metabolic lesion as well as the difficulty in explaining the clinical severity on the basis of abnormalities in the glycolytic energy metabolism of the red cell has been discussed thoroughly by Keitt (1966) .

Triosephosphate isomerase deficiency has been found in members of three families with CNHA. Two of the families are related and consanguinity exists in one of them. The common racial origin of the other family makes it possible that all three families have a common ancestry. Five children of these families were homozygotes and four of them presented severe anaemia in the 1st month of life but no neonatal jaundice, while the other one had severe enough jaundice to require exchange transfusion. Two more infants died early, one during exchange transfusion and the other on the 6th day from anaemia (Schneider et al., 1965; Shore, Schneider \& Valentine, 1965; Valentine et al., 1966). Progressive neurological disease and frequent bacterial infections with unexpected sudden death was the characteristic of the clinical histories in those surviving the neonatal period. This clinical picture suggested multiple tissue involvement. Actually the enzyme activity of white blood cells, muscle, cerebrospinal fluid and serum was found to be low 
in such patients (Schneider et al., 1968).

2,3-Diphosphoglycerate mutase deficiency was almost certainly the cause of severe anaemia at birth, but no jaundice, in an infant which demonstrated a severe haemolytic process for the duration of his life (he died from bronchopneumonia at 7 weeks). The parents were first cousins and the enzyme activity in them was $50 \%$ of the normal (Schröter, 1965). In two more cases with neonatal manifestations this enzyme defect was inferred from the low levels of 2,3-diphosphoglycerate (Löhr \& Waller, 1963; Lelong, Alagille \& Odievre, 1964). The clinical picture was completely different from the case of Schröter (1965) and we must assume either a different genetic variant or a defect in an enzyme proximal to 2,3-DPG mutase.

Hexokinase deficiency was found in a girl with severe anaemia and jaundice appearing in the first few hours of life and necessitated an exchange transfusion at the age of $4 \mathrm{hr}$ (Valentine et al., 1967). The haemolytic process continued after the neonatal period and frequent transfusions were required up to the time of splenectomy, following which she improved, although the haemolytic state remained. The critical position of hexokinase in the glucose metabolism of the red cell explains the severity of the haemolytic process in this case.

Glucose phosphate isomerase deficiency has been described in two families with CNHA. No clinical details have been published so far (Baughann et al., 1967; Holland et al., 1968).

Enzyme defects of the pentose phosphate pathway (PPP) other than glucose-6-phosphate dehydrogenase deficiency.

With the enzymes of PPP, glutathione reductase and peroxidase deficiency and congenital deficiency in glutathione will be examined as they are part of the same defensive mechanism of the erythrocyte against oxidative degradation. The importance of these mechanisms for the survival of the red cell under conditions of oxidative stress have been already mentioned. When this pathway cannot respond to such a stress an haemolytic crisis with red-cell fragmentation and Heinz-body formation results.

A minimum activity of PPP is required for the survival of the red cell under normal conditions even in the absence of any exogenous oxidative assault. If these minimum requirements cannot be met, chronic haemolysis results with the clinical picture of CNHA.

6-Phosphogluconate dehydrogenase deficiency (6PGD) is not connected with a uniform clinical picture. Heterozygotes with $50 \%$ enzyme activity have been described as asymptomatic (Brewer \& Dern, 1964) but one patient had CNHA with no evidence of susceptibility to drug-induced haemolysis (Scialom, Najean \& Bernard, 1966). Finally one male infant with 6-PGD deficiency had jaundice and anaemia in the first hours of life and an exchange transfusion was performed (Lausecker et al., 1965). At the age of 2-3 months this infant continued to have anaemia and slight jaundice.

Glutathione reductase deficiency (GSSG-R) with values of enzyme activity ranging from 16 to $50 \%$ of normal has been connected either with susceptibility to drug haemolysis (Carson, Brewer \& Ickes, 1961; Carson et al., 1963) or with CNHA (Löhr \& Waller, 1962; Waller et al., 1964, 1965). So far neonatal jaundice has not been associated with GSSG-R deficiency.

Glutathione peroxidase deficiency (GSH-P) of the red cells has been connected with severe neonatal jaundice and anaemia in the newborn period (Necheles, Boles \& Allen, 1968). Four cases have been described in Causasian newborns. Two of these infants were born pre-term. There was no history of exposure to haemolytic agents. The haemolysis was fairly severe and one of the infants was treated by exchange transfusion. Nevertheless all the infants were asymptomatic 3 months later and in this respect their course is similar with that of the G-6-PD deficient infants who develop severe jaundice. In vitro, the red cells demonstrated Heinzbody formation on incubation with acetylphenylhydrazine. From genetic evidence it was inferred that the infants were heterozygotes as only one of the parents had diminished enzyme activity. These cases demonstrated the precarious state of the red cells of the newborn in the face of endogenous peroxidation. Low catalase and GSH-P activity characterizes the red calls of the newborn and is one of the mechanisms for their increased sensitivity to oxidative drugs. Obviously the further depression of GSH-P activity due to a genetic defect explains the severity of haemolysis during the neonatal period even in heterozygotes.

Congenital absence of reduced glutathione (GSH) has also been connected with susceptibility to drug haemolysis but no reference of neonatal jaundice is found in the few cases reported (Oort, Loos \& Prins, 1961; Prins et al., 1966; Waller \& Gerok, 1964; Boivin \& Galland, 1965; Prins, Loos \& Zurcher, 1968).

\section{Glycose-6-phosphate dehydrogenase deficiency}

Glycose-6-phosphate dehydrogenase deficiency was discovered in the course of studies for the eluci- 
TABLE 3. Common variants of glucose-6-phosphate dehydrogenase

\begin{tabular}{|c|c|c|c|c|c|c|}
\hline Variant & $\begin{array}{l}\text { Activity in } \\
\text { red cells } \\
(\%)\end{array}$ & Race* & $\begin{array}{c}\text { Clinical } \\
\text { manifestations }\end{array}$ & $\begin{array}{l}\text { Substrate } \\
\text { affinity }\end{array}$ & $\begin{array}{l}\text { Substrate } \\
\text { analogue } \\
\text { utilization }\end{array}$ & $\begin{array}{l}\text { Basic effect } \\
\text { of mutation }\end{array}$ \\
\hline Normal $(\mathbf{B}+)$ & 100 & All & None & - & - & 一 \\
\hline Normal fast $(\mathbf{A}+)$ & 88 & Negro & None & Normal & Normal & $\begin{array}{l}\text { Structural mutation, Aspara- } \\
\text { gine replaced by aspartic acid } \\
\text { in enzyme molecule }\end{array}$ \\
\hline $\begin{array}{l}\text { Negro type of de- } \\
\text { ficiency (A-) }\end{array}$ & $10-20$ & Negro & $\begin{array}{l}\text { Drug induced } \\
\text { haemolysis - } \\
\text { self limited }\end{array}$ & Normal & Normal & $\begin{array}{l}\text { Structural mutation. Accelera- } \\
\text { ted degradation but normal } \\
\text { synthesis (normal activity in } \\
\text { young RBCs and WBCs) }\end{array}$ \\
\hline $\begin{array}{l}\text { Mediterranean } \\
\text { type of deficiency } \\
\text { (B-) }\end{array}$ & $0-7$ & $\begin{array}{l}\text { Greeks, Italians } \\
\text { Sephardic } \\
\text { Jews, Indians }\end{array}$ & $\begin{array}{l}\text { Drug induced } \\
\text { haemolysis. } \\
\text { Favism. Neo- } \\
\text { natal jaundice }\end{array}$ & Increased & Increased & $\begin{array}{l}\text { Structural mutation leading to } \\
\text { less activity per molecule and } \\
\text { accelerated degradation } \\
\text { (young RBCs and WBCs have } \\
\text { diminished activity) }\end{array}$ \\
\hline Canton & 4-24 & South Chinese & $\begin{array}{l}\text { Drug induced } \\
\text { haemolysis. Neo- } \\
\text { natal jaundice }\end{array}$ & Increased & $\begin{array}{l}\text { Slightly } \\
\text { Increased }\end{array}$ & $?$ \\
\hline
\end{tabular}

* In many populations with high incidence of G-6-PD deficiency the variant has not been fully characterized.

dation of the mechanism of the haemolytic effect of primaquine (Dern, Beutler \& Alving, 1954; Carson et al., 1959; Beutler, 1966). The development of relatively easy screening tests (Motulsky \& CampbellKraut, 1961 ; Fairbanks \& Beutler, 1962; Brewer et al., 1960 ; Bernstein, 1962) has permitted extensive population surveys. A high incidence has been found in populations around the Mediterranean, in Negroes, in many population groups of South Asia and among Chinese. On the basis of its geographical distribution, which coincides with that of endemic malaria, a selective advantage of G-6-PD deficiency in malarious areas was assumed (Motulsky, 1960, 1964). Extensive enzymological studies have revealed the heterogeneity of G-6-PD deficiency as well as variants of the enzyme with no functional consequences (Carson \& Frischer, 1966; Kirkman, Kidson \& Kennedy, 1968; Yoshida, Stamatoyannopoulos \& Motulsky, 1968).

A molecular weight of 240,000 and a composition from six sub-units of molecular weight 40,000 has been suggested from the characteristics of the purified and crystallized normal enzyme (Yoshida, 1966). Over forty variants of G-6-PD have been characterized so far. The distinction is based on enzyme activity in the erythrocytes and other cells, electrophoretic and column chromatography mobility, affinity for the main substrates (G-6-P and NADP) and for substrate analogues (2-desoxyglycose-6-phosphate and galactose-6-phosphate), heat lability, pH optimum, neutralization with specific antisera, estimation of enzyme activity in red cell precursors and young and old erythrocytes and finally on clinical manifestations and racial distribution.
The main characteristics of the common variants of G-6-PD are shown in Table 3. The A+ variant found in approximately $18 \%$ of the Negroes has no functional differences from the normal enzyme but moves faster in electrophoresis. Fingerprinting proved that it results from a single amino acid substitution, asparagine being replaced by aspartic acid (Yoshida, 1968). For the Negro type of G-6-PD deficiency (A-) a structural mutation is again suggested from its different behaviour on Sephadex column. The enzyme has normal activity per molecule but both in vitro and in vivo is easily and irreversibly inactivated. Young erythrocytes and nucleated cells (for instance white cells) which can synthesize new enzyme molecules, have normal enzyme activity. The overall effect of this variant can be described as accelerated ageing of the red cells. These characteristics explain the self-limited course of primaquineinduced haemolysis in the Negro type of G-6-PD deficiency (Kellermeyer et al., 1961).

In the Mediterranean type of G-6-PD deficiency (B-) the enzyme activity is almost zero and even the young cells and reticulocytes have greatly diminished activity (one-third of normal). The decay of the enzyme is also accelerated. A structural mutation is again suggested leading to disturbance of the secondary and tertiary configuration of the enzyme molecule and thus to diminished activity per enzyme molecule and accelerated degradation (Yoshida et al., 1968). These characteristics explain: (a) the more severe haemolytic effect of primaquine and the absence of a refractory period in subjects with this type of G-6-PD deficiency (Salvidio et al., 1967; George et al., 1967). (b) The fact that the list of drugs that produce haemolysis is more extensive 
than that for the Negro-type of G-6-PD deficiency and includes also four beans.

All G-6-PD variants are alleles at the same locus of the $\mathrm{X}$ chromosome (sex-linked). The sex-linkage of the enzyme defect results in the existence of two types of males, i.e. normal and hemizygote defective; and three types of females, i.e. normal homozygotes, defective homozygotes and heterozygotes with one $\mathrm{X}$ chromosome carrying the normal gene and the other $\mathrm{X}$ carrying the gene for the abnormal variant. In the case of the heterozygotes the red-cell population should be considered a mosaic according to the Lyon-effect with a proportion of the red cell population derived from normoblasts with active $\mathrm{X}$ chromosomes with the normal genes (normal enzyme activity) and the remaining red cells from normoblasts with active $\mathrm{X}$ chromosomes with abnormal genes (decreased enzyme activity). This situation explains the difficulties in detecting the heterozygote females with laboratory methods based on the enzyme activity of the whole red-cell population. The level of enzyme activity, within the normal range, seems to be controlled by normal alleles (isoalleles) and thus is also genetically determined (Davidson, Childs \& Siniscalco, 1964; Motulsky \& Stamatoyannopoulos, 1966).

The metabolic consequences of the primary defect in G-6-PD activity and their relation to druginduced haemolysis have been extensively studied but there are still some points poorly understood (Beutler, 1966; Carson \& Frischer, 1966). Several mutants of G-6-PD cause chronic haemolysis in the absence of exogenous haemolytic agents. In such cases exacerbation of haemolysis occurs during infection or administration of haemolytic drugs. Although fairly common among the enzymopathies causing CNHA these variants remain extremely rare in comparison with the common mutants of G-6-PD deficiency which are associated with druginduced haemolysis.

The variants connected with CNHA have been found mainly in Caucasians of North European origin but there is no reason to believe that such mutations have not occurred in other racial groups. The characterization of these variants with a variety of enzymological techniques showed that they differ from the normal and the other common variants in having, decreased thermal stability (Kirkman et al., 1964b; Beutler, Mathan \& Smith, 1968), decreased affinity for G-6-P or/and NADP (Pinto et al., 1966; Beutler et al., 1968) and differences in the pH optimum (Beutler, 1968). Some other variants have not as yet been characterized in detail. The abnormal stability and kinetics of the enzyme variants explain the severity of haemolysis. Recently defective synthesis of the enzyme has been described (Piomelli et al., 1968). The enzyme was found to be absent even in the red cell precursors while in the Negro and Mediterranean type of G-6-PD deficiency the activity is normal in the precursors but declines rapidly because of in vivo instability.

In several cases of CNHA from G-6-PD deficiency severe neonatal jaundice and anaemia were prominent (Newton \& Bass, 1958; Newton \& Frajola, 1958; Shahidi \& Diamond, 1959; Zinkham \& Lenhard, 1959; Kirkman \& Riley, 1961; Tada, 1961 ; Bernard et al., 1963; Greenberg \& Tanaka, 1965) and actually it was in these cases that the association between severe neonatal jaundice and a red cel enzyme defect was first demonstrated. The connection between G-6-PD deficiency and severe neonatal jaundice will be examined in detail in the discussion that follows.

Severe jaundice in G-6-PD deficient neonates following exposure to haemolytic agents

The association between G-6-PD deficiency and severe neonatal jaundice has been reported from almost every ethnic group in which this enzymopathy is known to occur. In many of these reports an exogenous haemolytic agent could be implicated. The infant was either exposed to the substance directly or through the placental circulation or the breast milk. The list of substances implicated in the production of haemolysis and severe jaundice in susceptible newborns includes

(a) Naphthalene (moth balls) usually inhaled but also absorbed through the skin or from breast milk after ingestion by the mother (Zinkham \& Childs, 1957, 1958; Dawson, Thayer \& Desforges, 1958; Valaes, Fessas \& Doxiadis, 1961 ; Valaes et al., 1963; Jim \& Chu, 1963; Naiman \& Kosoy, 1964).

(b) Long acting sulphonamide given to the mother (Brown \& Cevik, 1965).

(c) Acetylsalicylic acid and phenacetin (Lee et al., 1961 ; Harley \& Robin, 1962, 1963).

(d) 'Triple dye', a local antiseptic applied to the umbilical stump (Freier et al., 1965).

(e) Combinations of agents (Ifekwunigwe \& Luzzato, 1966).

The group with naphthalene inhalation is the largest. In many of the cases the circumstances of the exposure suggest that only a minute amount of the substance could have been absorbed by the infant, yet the ensuing haemolysis was dramatic with an abrupt drop in the haemoglobin concentration and occasionally with haemoglobinuria and methaemoglobinuria. Fragmentation and Heinzbody formation in a large proportion of the erythrocytes was also noted in many cases (Valaes et al., 1963). The level of bilirubin was related not only to the degree of haemolysis but also to the age of the infant. The earlier the exposure to the haemolytic agent, naphthalene or other, the higher the level of 
bilirubin tended to rise. In many cases kernicterus occurred even before an appreciable anaemia had time to develop (Valaes et al., 1961, 1963; Naiman \& Kosoy, 1964). It should be noted that a similar, but somewhat milder, haemolytic effect of naphthalene was seen in a few infants with no demonstrable enzyme defect (Valaes et al., 1963).

Vitamin $\mathrm{K}$ analogues, in large doses, have been connected with hyperbilirubinaemia and kernicterus particularly in premature newborns (Gasser, 1953; Allison, 1955; Lawrence, 1955; Crosse, Meyer \& Gerrard, 1955; Meyer \& Angus, 1956; Bound \& Telfer, 1956; Lucey \& Dolan, 1959). Overt haemolysis and evidence of a toxic effect, as expressed by the presence of Heinz-bodies in the erythrocytes of many of the reported cases, clearly demonstrate that vitamin $\mathrm{K}$ analogues can stress the limited resources of anti-oxidant mechanisms of the newborn. In vitro it was shown that incubation of the red cells of the newborn with menandione sodium bisulphite lowered the glutathione content similarly to acetylphenylhydrazine (Zinkham, 1959). The vulnerability of the G-6-PD deficient red cells to oxidants makes it likely that vitamin $\mathrm{K}$ analogues will also be damaging to them. Among Greek infants with severe jaundice connected with G-6-PD deficiency those who received these analogues, even in small doses, presented with a much higher percentage of kernicterus than the remainder. In many of these infants fragmented erythrocytes, Heinz-body formation and low haemoglobin values formed a clearcut picture of haemolytic crisis (Doxiadis et al., 1961 ; Valaes et al., 1961; Doxiadis \& Valaes, 1964). It has to be admitted that in most cases the analogues were given after the onset of the jaundice.

Two controlled trials, in Negro populations, failed to show any effect of even large doses of vitamin $K$ analogues on the serum bilirubin levels of G-6-PD deficient newborns (Capps et al., 1963; Zinkham, 1963). In the study of Zinkham it was suggested that natural vitamin $\mathrm{K}_{1}$ lowered the levels of serum bilirubin.

Thus at present there is circumstantial evidence that in newborns with the more severe, Mediterranean, type of G-6-PD deficiency vitamin $\mathrm{K}$ analogues may have an haemolytic effect, even in small doses, while controlled experiments demonstrated the absence of such an effect in newborns with the Negro type of G-6-PD deficiency.

\section{Spontaneous severe jaundice in G-6-PD deficient newborns}

In a number of surveys the incidence of G-6-PD deficiency in groups of infants with severe jaundice and kernicterus was examined. In a high proportion of infants, with otherwise unexplained severe jaundice, G-6-PD deficiency was demonstrated among Sardinian (Panizon, 1960a,b), Chinese (Smith \& Vella, 1960; Yue \& Strickland, 1965; Lu, Wei \& Blackwell, 1966; Wong, 1964, 1966; Brown \& Wong, 1968), Greek (Doxiadis, Fessas \& Valaes, 1960; Fessas, Doxiadis \& Valaes, 1962; ZannosMariolea et al., 1968), Thai (Flatz et al., 1963), Malay (Wong, 1966) and Turkish (Say et al., 1965) newborns. In these ethnic groups G-6-PD deficiency was one of the major causes of severe jaundice and even more the major cause of kernicterus. An exogenous haemolytic agent could not be demonstrated in the majority of the infants. In the case of Chinese newborns traditional herbs used in the care of mother and baby were blamed. As nothing mysterious or exceptional was used in the conduct of labour and the care of the mothers and infants in most of the Greek and Italian cases, it was claimed that severe jaundice could develop in G-6-PD deficient newborns in the absence of an exogenous haemolytic agent.

The main clinical characteristics of this type of jaundice (Doxiadis \& Valaes, 1964) are as follows:

(a) In the majority of the cases (70-75\%) the onset of jaundice occurs between the 2nd and 3rd day of life. In a small proportion (10-15\%) of the infants jaundice is noted within the first $24 \mathrm{hr}$ of life. Onset on the 4th or up to the 8th day of life has also been recorded. No correlation seems to exist between the time of the onset of the jaundice and the severity of subsequent hyperbilirubinaemia. From the clinical point of view it should be stressed that in most cases the time of onset of the jaundice is similar to that of the so-called 'physiological jaundice' although the course and outcome are quite different. In some infants the late onset of jaundice and continuous rise of serum bilirubin well into the 2nd week of life, made it possible for kernicterus to develop after the infants had left the maternity ward. This explains why, in areas where severe neonatal hyperbilirubinaemia from other causes is effectively managed, kernicterus still occurs in G-6-PD deficient newborns.

(b) Kernicterus can occur or the necessity for exchange transfusion arise as early as the 2 nd day of life and as late as the 11 th day. In $65 \%$ of the cases the decisive point in the course of hyperbilirubinaemia is reached on the 3rd, 4th or 5th day of life.

(c) The jaundice is self-limited although protracted in its course. Unless kernicterus supervenes, prognosis is good as there is no evidence of continuing haemolysis outside the neonatal period (except under the influence of an exogenous haemolytic agent). In this respect there is no resemblance to the sporadic cases of G-6-PD deficiency connected with CNHA.

(d) The proportion of the red-cell population haemolysed in the course of the jaundice varies from 
one case to the other. Usually a small proportion of the red cells is destroyed and no frank anaemia develops. In other cases the destruction affects almost all the red cells. Extreme anaemia develops in a few days and most of the red cells in the peripheral blood are fragmented and contain Heinz-bodies. In accordance with these clinical observations the few cases which have been studied with autotransfusion showed ${ }^{51} \mathrm{Cr}$ half-lives varying from 8 to 22 days (personal material; Schettini et al., 1963).

(e) Females, proved to be heterozygotes on genetic grounds (i.e. G-6-PD deficient father) and with enzyme activity of the red-cell population within the normal range, can exhibit equally severe degrees of jaundice. In these cases the haemolysis of a large proportion of the red cells of the G-6-PD deficient clone is sufficient to produce severe hyperbilirubinaemia. The male/female ratio in large series of infants with severe neonatal jaundice from G-6-PD deficiency has varied from 3.0 (Doxiadis \& Valaes, 1964) to 1.5 (Zannos-Mariolea et al., 1968.) The smaller ratio was obtained by using more sensitive laboratory methods for the detection of female heterozygotes.

(f) The cases of severe jaundice from G-6-PD deficiency are not equally distributed in the whole group of G-6-PD deficient newborns. There is a strong familiar predisposition (Panizon, 1960b; Weatheral, 1960) which can best be explained by the hypothesis that a second independently transmitted hereditary factor is necessary for the development of severe jaundice in G-6-PD deficient neonates (Fessas et al., 1962).

\section{Surveys of the incidence of neonatal jaundice among G-6-PD deficient newborns}

In Table 4 we have tabulated the results of all the available surveys, in which the relationship of G-6-PD deficiency and neonatal hyperbilirubinaemia have been examined in consecutive series of newborns. Because of differences in the criteria of severe jaundice and the general planning of the surveys these cannot be considered to be strictly comparable. For example in the Greek surveys of the populations of Southern Greece and of Lesbos, the surveys in the regions of Bangkok, Hong-Kong and Ibadan, serum bilirubin was determined only in those infants judged to have moderate or marked jaundice, those with serum bilirubin values of 15-16 $\mathrm{mg} / 100 \mathrm{ml}$ or over were included in the group with severe jaundice. In the surveys at Rhodes (Greece), Formosa and among Negroes in U.S.A., the bilirubin was determined in all infants with G-6-PD deficiency and a group of controls.

The differences in the methods and criteria and possibly differences in the bilirubin values between the laboratories involved, cannot account for the differences in the incidence of severe jaundice among the G-6-PD deficient newborns in the various surveys.

The results of the surveys listed in Table 4 suggest that there are three types of populations in relation to the incidence of hyperbilirubinaemia in G-6-PD deficient male newborns: (1) Populations with the severe type of G-6-PD deficiency (Mediterranean type) and an incidence of severe neonatal jaundice of $5-10 \%$. This group includes the Greeks of the Southern part of Greece and of Rhodes and also the Chinese and Thais of the Bangkok region. (2) Populations with the severe type of G-6-PD deficiency and an incidence of severe neonatal jaundice of $25-45 \%$. This group includes the Greeks of Lesbos, the Chinese of Hong-Kong, Formosa and Singapore, and probably the Turks of the region of Ankara. (3) Populations with the milder, Negro-type, of G-6-PD deficiency and with very little associated severe neonatal jaundice. Obviously there must be several other populations belonging to one of the above categories that have not yet been investigated in this manner. A retrospective study by Szeinberg and his associates (Szeinberg et al., 1963) among different communities of non-Ashkenazi Jews with extremely high frequencies of G-6-PD deficiency of the severe type, failed to show any relation between G-6-PD deficiency and severe jaundice. Only among Iraq Jews such a relation seemed to exist.

The incidence of severe jaundice among hetero zygote female newborns has not been studied in all the surveys. The screening procedures employed for the detection of G-6-PD deficiency only in the hands of Flatz and his associates (Flatz et al., 1963, 1964) succeeded in detecting most of the heterozygote female newborns (as judged from the comparison between the number found and that expected from the gene frequency, i.e. frequency of male hemizygotes). In the population of Rhodes, Valaes and his associates (Valaes et al., 1968) collected family data and estimated quantitatively the activity of G-6-PD in all the females with severe jaundice. The number found to be heterozygotes for G-6-PD deficiency was referred to the expected number in the whole population studied. In this population an almost equal number of female newborns had severe jaundice as male newborns but in the latter the jaundice was much more severe and kernicterus occurred only in them.

The question of exogenous haemolytic agents being the cause of severe jaundice in all the G-6-PD deficient newborns with this manifestation could be easily ruled out in the above surveys. No relation could be found between the usual drugs used during labour and the development of severe jaundice and nothing mysterious was used in the care of mother and baby. 


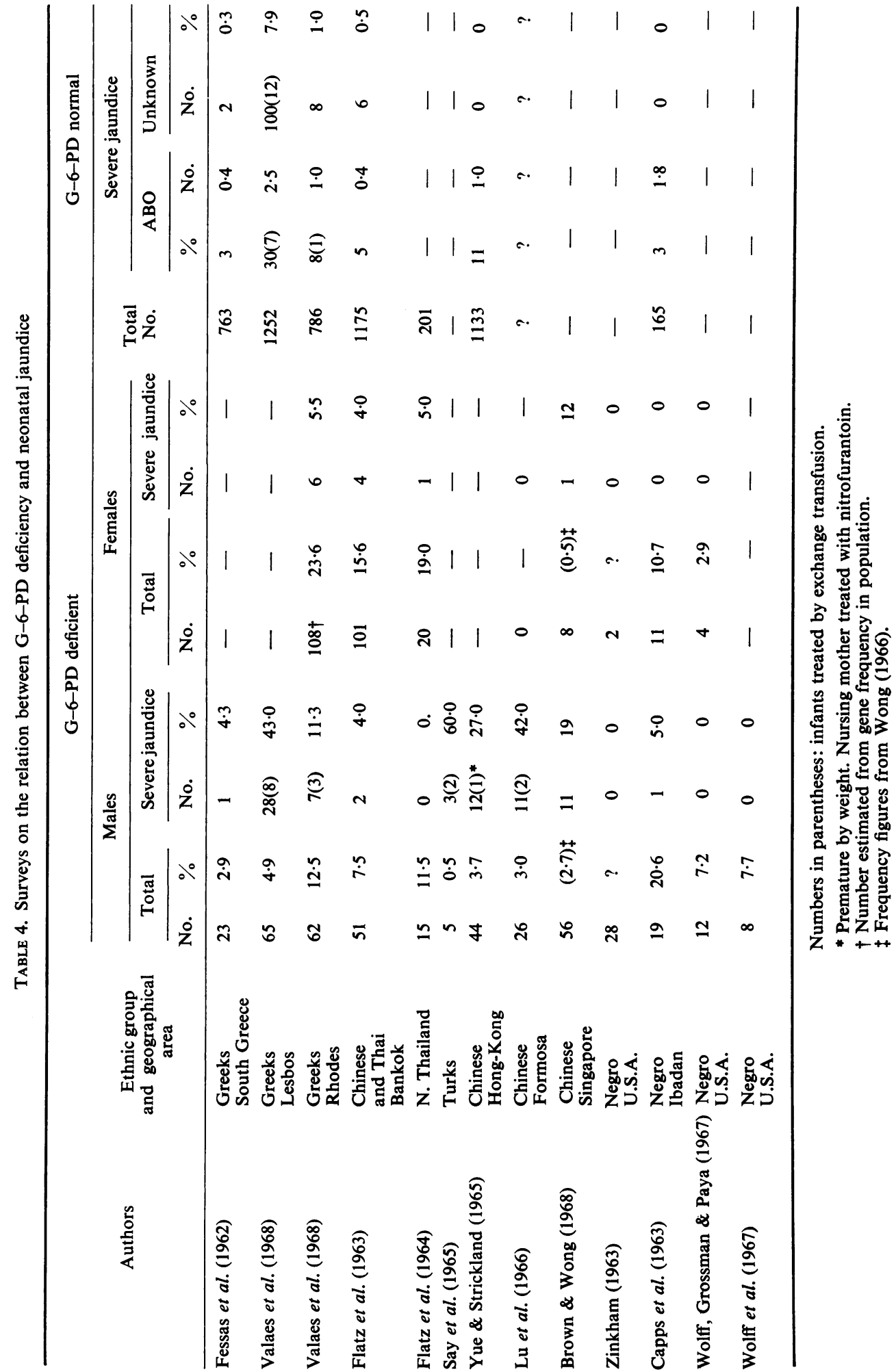


Cord blood findings in infants with G-6-PD deficiency of the Mediterranean type have been studied in the island of Rhodes, Greece (Valaes et al., 1968) and in Singapore (Brown \& Wong, 1968). In comparison with a control group, male infants with G-6-PD deficiency had a significantly lower mean haemoglobin concentration and higher serum bilirubin one, but there was no significant difference in the reticulocyte count. The lower mean haemoglobin concentration was the result of a shift towards lower values of the whole distribution curve of cord blood haemoglobin and was not due to a group of G-6-PD deficient infants with very low values. In the 'Rhodes' survey the serum bilirubin concentration on the 4th day was $7.88 \pm 4.8$ in the control group and $9.86 \pm 6.6$ in infants with G-6-PD deficiency, full term and with no blood group incompatibility. In the 'Singapore' survey the maximum serum bilirubin for the Chinese newborn infants was $11.2 \pm 3.7$ in the controls and 15.5 \pm 3.4 in the G-6-PD deficient infants. The above in combination with the findings in the cord blood and lower haemoglobin values on the 4th day clearly demonstrate that the G-6-PD deficient newborns as a group, have increased rates of haemolysis starting from the intrauterine life and continuing after birth leading to higher degrees of neonatal hyperbilirubinaemia in comparison with infants with normal G-6-PD activity. In a similar study in Formosa the higher mean serum bilirubin value of the G-6-PD deficient infants, in comparison with a control group, was obvious even at the first $24 \mathrm{hr}$ of life. This again points to an early, intrauterine, onset of haemolysis (Lu et al., 1966). In the 'Rhodes' survey it was not clear whether the infants with extreme degrees of hyperbilirubinaemia (including three cases of kernicterus) were the upper end of a continuous spectrum of severity or constituted a separate group.

These data are of considerable importance as they refute the notion that hyperbilirubinaemia in G-6-PD deficient neonates is always the result of some noxious, albeit unidentified, exogenous haemolytic agent.

In populations with the Negro type of G-6-PD deficiency where the deficient infants do not have higher bilirubin levels in comparison with the normal controls (O'Flyn \& Hsia, 1963; Zinkham, 1963) severe neonatal jaundice develops if G-6-PD deficiency is combined with prematurity (Capps et al., 1963; Botha et al., 1967) or other contributory factors (Levin, Charlton \& Freiman, 1964; Hendrickse, 1965; Brown, 1966).

In a survey at Philadelphia (Oski, Eshagpour \& Williams, 1966; Eshagpour, Oski \& Williams, 1967) the combination in Negro infants of G-6-PD deficiency and prematurity produced levels of serum bilirubin above $20 \mathrm{mg} / 100 \mathrm{ml}$ in seven out of fourteen infants and six infants required exchange transfusion. In comparison with controls the deficient premature infants had a larger drop in haemoglobin values and higher reticulocyte counts. This increased vulnerability of the premature G-6-PD deficient infants is probably the result of both their decreased bilirubinconjugating capacity and their precarious red-cell metabolism which in the presence of G-6-PD deficiency leads to rates of haemolysis greater than the ones existing in term G-6-PD deficient newborns. Another important fact becomes apparent from the data in Table 4. A correlation exists between the incidence of severe jaundice in the G-6-PD deficient newborns and the incidence, among the normal $\omega$ newborns of the same population, of severe jaundice without foeto-maternal blood group incompatibility. Thus in Lesbos unexplained severe jaundice was much more frequent than in either the population of $i$ Rhodes, Southern Greece or the Bangkok region. It N seems that in certain regions or populations an $\infty$ icterogenic factor exists, which alone is capable of producing severe jaundice in some infants. In the same populations the combination of this unknown $\overrightarrow{-}$ factor and G-6-PD deficiency leads to the development of severe jaundice in a large proportion of the infants of the latter group (Valaes \& Karaklis, 1967; Brown \& Wong, 1968).

The presence of an icterogenic factor was demono strated for the first time in Lesbos and was relatef. to the high incidence of severe jaundice bot among the G-6-PD deficient and the normal infants (Doxiadis et al., 1964). In a later study the level of serum bilirubin in male full-term infants without foeto-maternal incompatibility and with normal G-6-PD activity from Lesbos was compared with a similar group from Rhodes (Valaes et al., 1968). The Lesbos group had significantly higher serum bilirubin values $(9 \cdot 43 \pm 4 \cdot 3$ versus $7 \cdot 88 \pm 4 \cdot 8)$. These results suggest that the unknown icterogenic factor was operating in a large enough percentage of the population to shift the whole distribution curve of neonatal hyperbilirubinaemia towards higher values. The combination of this factor with G-6-PD deficiency occurred with such frequency as to raise the incidence of severe neonatal jaundice in the G-6-PD deficient infants to $43 \%$.

In another part of the world the existence of an icterogenic factor was also demonstrated. Brown \& Wong (1965) showed differences in the peak serum bilirubin values between British and Asiatic neonates born in the same hospitals in Singapore. The peak serum bilirubin was $4.4 \mathrm{mg} / 100 \mathrm{ml}$ for British, $11.2 \pm 3.7 \mathrm{mg}$ for Chinese, $10 \cdot 0 \pm 3.3 \mathrm{mg}$ for Malay and $9.6 \mathrm{mg}$ for the Indian newborns. In the same study it was also noticed that the peak serum bilirubin was reached later in Asiatic newborns. These observations confirmed earlier reports that 'physiological 
jaundice' was more frequent, more marked and of longer duration among Chinese newborns ( $\mathrm{Lu}$, Lee \& Chen, 1963; Wong, 1964).

Differences in the level of neonatal hyperbilirubinaemia of full-term and even more of pre-term infants existed between previous surveys (Hsia et al., 1953; Dine, 1954; Obrinsky, Allen \& Anderson, 1954; Holman, 1958). Rightly they were ascribed either to poor standardization of laboratory methods for the estimation of bilirubin (Mather, 1960; Lucey, Phillips \& McKay, 1960; Westphal, Viergiver \& Roth, 1962) and/or to factors in the medical and nursing care of the newborns which could influence the bilirubin levels (Lucey, 1960). Such an explanation cannot be held for either the Greek or the Singapore survey. Thus we have to accept that there are racial and regional differences in the level of neonatal hyperbilirubinaemia. As for the mechanism of these differences the evidence so far is inconclusive. In Lesbos, the group of infants with severe jaundice but without incompatibility or G-6-PD deficiency had as a whole lower haemoglobin values in comparison with the control group, yet, within the group, those that required an exchange transfusion had significantly higher haemoglobin levels. Thus we cannot be sure that haemolysis was the main mechanism for the development of the severe jaundice. Similarly the control group of the Lesbos survey (which had higher serum bilirubin values) had haemoglobin values both in the cord blood and on the 4th day, higher than the corresponding Rhodes survey group. Data on haemoglobin are not given for the surveys of Singapore and Formosa and thus only hypotheses can be made for the mechanism of increased 'physiological jaundice' in those populations.

\section{Conclusions and hypothesis}

The evidence so far mentioned can help us reach a few conclusions as to the explanation for the varying risk of severe jaundice in G-6-PD deficient newborns in different populations.

Glucose-6-phosphate dehydrogenase deficiency of the severe type produces a shortening of the lifespan of the red cells in the foetal and newborn period. This shortening is sufficient to lower the haemoglobin and raise the serum bilirubin values of the whole group but not enough to produce a significant reticulocyte response or frank anaemia. The increased rate of haemolysis of the group acquires clinical significance in a varying proportion of cases when combined with other icterogenic factors. A variety of such contributory factors have been identified so far: (a) Prematurity, affecting either the excretion of bilirubin or the metabolism of the red cells or even both. (b) ABO incompatibility (per- sonal material). (c) An unknown genetic factor acting in some families. (d) An unknown icterogenic factor existing in some races or regions.

It is evident from the above that the explanation for the development of severe neonatal jaundice in some of the infants with G-6-PD deficiency should be sought outside the enzyme deficiency itself. Actually no difference was found in the enzyme characteristics between infants with G-6-PD deficiency who did and did not develop severe neonatal jaundice (Kirkman et al., 1965).

The unknown icterogenic factor existing in some racial groups could operate either by increasing production or decreasing excretion of bilirubin (delayed induction of glucuronyl transferase activity or inhibition of conjugation). This factor again could be either environmental in origin (food constituents, trace elements, popular herbs, etc.) or genetic. The environmental origin seems unlikely as there is very little in common between, for instance, Lesbos and Formosa, Greek and Chinese habits. If the factor is genetic it must be conferring a selective advantage in special environmental conditions to balance out the disadvantage of the increased loss from kernicterus. It is difficult to see what possible selective advantage delayed maturation of the conjugating capacity of the liver could have. The possibility of a metabolic profile of the neonatal red cells, that leads to a slight shortening of their life span, to have a selective advantage, is worth examining.

The hypothesis proposed by Brewer \& Powell (1965) is in this respect very attractive. These workers found an inverse relationship between erythrocyte ATP levels and the time lapse for the development of significant parasitaemia in experimental falciparum malaria in non-immune subjects. It is likely that low levels of ATP lead to a shortening of the life span of the erythrocyte so that the parasite does not have enough time to complete its asexual cycle and thus significant parasitaemia is delayed. There is already evidence that ATP levels are under multifactorial control and depend on the whole metabolic profile of the red cells.

Whatever the icterogenic factor may be it is very likely from the data so far available (see Table 4) that the G-6-PD deficiency gene and this factor are mutually exclusive. A low incidence of unspecified neonatal jaundice exists in the populations with high frequency of G-6-PD deficiency, for instance nonAshkenazi Jews, Negroes, Greeks of Rhodes, and on the contrary in populations with increased neonatal hyperbilirubinaemia the incidence of G-6-PD deficiency has been found to be low. Clearly there is a need for more detailed information on the global epidemiology of neonatal jaundice and the problem is worthy of our attention from many aspects. 


\section{References}

Allison, A.C. (1955) Danger of vitamin $K$ to newborn. Lancet, i, 669.

ARIAS, I.M., Johnson, L. \& Wolfson, S. (1961) Biliary excretion of injected conjugated and unconjugated bilirubin by normal and Gunn rats. Amer. J. Physiol. 200, 1091.

ARIAS, I.M., GARTNER, L.M., SEIFTER, J. \& FurmaN, M. (1964) Prolonged neonatal unconjugated hyperbilirubinaemia associated with breast feeding and a steroid, pregnane3(alpha)-20(beta)-diol, in maternal milk that inhibits glucuronide formation 'in vitro'. J. clin. Invest. 43, 2037.

ARIAS, I.M., WolfSON, S., LUCEY, J.F. \& MCKAY, R.J. (1965) Transient familial neonatal hyperbilirubinemia. J. clin. Invest. 44, 1442.

BAKKeN, A.F. \& FoG, J. (1967a) Bilirubin conjugation in the newborn. Lancet, i, 1280.

BAKKEN, A.F. \& FOG, J. (1967b) Bilirubin conjugation in newborn rats. Lancet, ii, 309.

Baugham, M.A., Valentine, W.N., Paglia, D.E., Ways, P.O., Simon, E.R. \& De MARSH, Q.B. (1967) Hereditary hemolytic anemia associated with glucose phosphate isonerase (GPI) deficiency. A new enzyme defect of human erythrocytes. Blood, 30, 850 .

Bernard, J., Taurer, J., NaJean, X., Moulinier, J., Scialom, C., Levey, J.P. \& PeTrover, M. (1963) La forme chronique de l'anémie hémolytique héreditaire par insuffisance en glucose-6 phosphate déshydrogénase. Observations préliminaires sur une famille française. Nouv. Rev. franc. Hemat. 3, 465.

Bernstein, R.E. (1962) A rapid screening dye test for the detection of glucose-6-phosphate dehydrogenase deficiency in red cells. Nature (Lond.), 194, 192.

Bestetti, A., Rossi, V., Loos, J.A. \& Prins, H.K. (1964) A case of congenital atypical haemolytic anaemia with pyruvate kinase deficiency. Vox Sang. (Basel), 9, 492.

BeuTler, E. (1966) Glucose-6-phosphate dehydrogenase deficiency. Metabolic Basis of Inherited Disease (Ed. by J.B. Stanbury, J.B. Wyngaarden and D.S. Fredrickson). MacGraw Hill, New York.

Beutler, E., Mathan, C.K. \& Smith, J.E. (1968) Biochemical variants of glucose-6-phosphate dehydrogenase giving rise to congenital nonspherocytic hemolytic disease. Blood, 31, 131 .

BILling, B.H. \& LATHE, G.H. (1958) Bilirubin metabolism in jaundice. Amer. J. Med., 24, 111.

BoIvin, R. \& GallaRd, C. (1965) La synthése du glutathion au cours de l'anémie hémolytique congénitale avec déficit en glutathion réduit. Nouv. Rev. franc. Hemat. 5, 707.

Borvin, R. \& Malarme, J. (1963) Anémie hémolytique congénitale avec déficit en pyruvate kinase. Pressé Med. 71 1412.

Botha, M.C., Rees, J., Pritchard, J. \& Van ZyL L. (1967) Glucose-6-Phosphate dehydrogenase deficiency and neonatal jaundice among population groups of Cape Town. S. Afr. med. J. 41, 174.

Bound, J.P. \& TelFeR, T.P. (1965) Effects of vit. K dosage on plasma bilirubin levels in prematures. Lancet, $\mathbf{i}, 720$.

Bowdler, A.J. \& Prankerd, T.A.J. (1964) Studies in congenital non-spherocytic haemolytic anaemias with specific enzyme defects. Acta Haemat. 31, 65.

BowmanN, H.J., McKusick, V.A. \& Drowamrazu, K.R. (1965) Pyruvate kinase deficient hemolytic anemia in an Amish isolate. Amer. J. hum. Genet. 17, 1

Bracci, R., Seeler, R., Rudolph, N., Kochen, J.N. \& CRoss, R.T. (1965) Erythrocyte glutathione peroxidase activity and hydrogen peroxide sensitivity: A mechanism for drug-induced hemolysis. J. Pediat. 67, 938.

Brewer, G.J., Alving, I., Tarlov, B. \& Alving, A.S (1960) Methaemoglobin reduction test. A new simple in vitro test for identifying primaquine-sensitivity. Bull. Wld Hlth Org. 22, 633.

BREWER, J. \& DERN, R.J. (1964) A new inherited enzymatic $\stackrel{\mathbb{D}}{\varrho}$ deficiency of human erythrocytes: 6-phosphogluconate de- $C$ hydrogenase deficiency. Amer. J. hum. Genet. 16, 472.

BREWER, G. J. \& Powell, R.D. (1965) A study of the relationship between the content of Adenosine triphosphate in human red cells and the course of falciparum malaria. A new system that may confer protection against malaria. Proc. nat. Acad. Sci. (Wash.), 54, 741.

Brown, A.K. (1962) Neonatal jaundice. Pediat. Clin. N.Amer. 9, 575.

Brown, A.K. (1966) Discussion. American Pediatric Society meeting. J. Pediat. 69, 904.

Brown, A.K. \& BURNETT, H. (1957) Studies on the neonatal development of the glucoronide conjugating system. Amer. J. dis. Child. 94, 510.

Brown, A.K. \& Cevik, N. (1965) Hemolysis and jaundice in the newborn following maternal treatment with sulfamethoxypyridazine (Kynex). Pediatrics, 36, 742.

Brown, W.R. \& WoNG, H.B. (1965) Ethnic group differences in plasma bilirubin levels of full-term healthy Singapore newborns. Pediatrics, 36, 745.

Brown, W.R. \& WoNG, H.B. (1968) Hyperbilirubinaemia and kernicterus in glucose-6-phosphate dehydrogenase deficient infants in Singapore. Pediatrics, 41, 1055.

Brown, A.K., Zuelzer, W.W. \& BurNeTt, H.H. (1958) Studies on the neonatal development of the glucuronide conjugating system. J. clin. Invest. 37, 332.

Brunetri, P., PuXeddu, A., Nenci, G. \& Migliorini, E. (1963) Hemolytic anemia due to pyruvate-kinase deficiency. Lancet, ii, 169.

BusCH, D. (1963) Erythrocyte metabolism in three person with hereditary non-spherocytic haemolytic anaemia deficient in pyruvate kinase. Proc. 9th Congr. Europ. Sa Haemat. Lisbon, p. 783. Karger, Basel.

BusCh, D., WITT, I., Berger, M. \& Kunzer, W. (1966 Deficiency of Pyruvate kinase in the erythrocytes of a child with hereditary Non-spherocytic hemolytic anaemia. Acta pediat. Scand. 55, 177.

CaPps, F.P.A., Gilles, H.M., Jolly, H. \& Worlledge, S.M. (1963) G.6.PD deficiency and neonatal jaundice in Nigeria. Their relation to the use of prophylactic vitamin K. Lancet, ii, 379.

Careddu, P., Piceni-Sereni, L., Guinta, A. \& Sereni, F. (1964) Sulla possibilita di attivare i processi di conjugazione e di excrezione epatica della bilirubina mediante alcuni farmaci. Min. Medica (Torino), 55, 2555.

CARson, P.E. (1960) Glucose-6-phosphate dehydrogenase deficiency in hemolytic anemia. Fed. Proc. 19, 995.

Carson, P.E., Brewer G.J. \& ICKeS, C. (1961) Decreased glutathione reductase with susceptibility to hemolysis. J. Lab. clin. Med. 58, 804.

Carson, P.E., Flanagan, C.L., Ickes, C.E. \& Alving, A.S. (1956) Enzymatic deficiency in primaquine-sensitive erythrocytes. Science, 124, 484.

Carson, P.E. \& Frischer, H. (1966) Glucose-6-phosphate dehydrogenase deficiency and related disorders of the pentose phosphate pathway. Amer. J. Med. 41, 744.

Carson, P.E., Okita, G.T., Frischer, H., Hirasa, J. LONG, W.K. \& BREWER, G.J. (1963) Patterns of hemolytic susceptibility and metabolism. Proc. 9th Congr. European Soc. Haemat. Lisbon, p. 655. Karger, Basel.

Carson, P.E., Schrier, S.L. \& KellermeYer, R.W. (1959) Glucose-6-Phosphate dehydrogenase and human erythrocytes. Characteristics of glucose-6-phosphate dehydrogenase from normal and primaquine sensitive erythrocytes. Nature (Lond.), 184, 1291.

Carson, P.E. \& Tarlov, A.R. (1962) Biochemistry of hemolysis. Ann. Rev. Med. 13, 105. 
Chan, T.K., Todd, P. \& Wong, C.C. (1965) Tissue enzyme levels in erythrocyte glucose-6-phosphate dehydrogenase deficiency. J. Lab. clin. Med. 66, 937.

Childs, B., Zinkham, W., Browne, E.A., Kimbro, E.L. \& TORBERT, J.V. (1958) A genetic study of a defect in glutathione metabolism of the erythrocyte. Bull. Johns Hopk. Hosp. 102, 21.

Cracco, J.B.B., Dower, J.C. \& Harris, L.E. (1965) Bilirubin Metabolism in the newborn. Proc. Mayo Clin. 40, 868.

Crigler, J.F. \& Gold, N.I. (1966) Sodium Phenobarbital induced decrease in serum bilirubin in an infant with congenital nonhemolytic jaundice and kernicterus. $J$. clin. Invest. 45, 998.

Crosse, V.M., Meyer, T.C. \& Gerrard, J.W. (1955) Kernicterus and Prematurity. Arch. Dis. Childh. 30, 501.

Dacie, J.V., Mollison, P.L., Richardson, N., Selwyn, J.G. \& ShapIRo, L. (1953) Atypical congenital haemolytic anaemia. Quart. J. Med. 22, 79.

Davidson, R.G., Childs, B. \& Siniscalco, M. (1964) Genetic variations in the quantitative control of erythrocyte glucose-6-phosphate dehydrogenase activity. Ann. hum. Genet. 28, 61.

Dawson, J.P., Thayer, W.W. \& Desforges, J.F. (1958) Acute hemolytic anemia in the newborn infant due to naphthalene poisoning: report of two cases with investigations into the mechanism of the disease. Blood, 13, 1113.

Dern, R.J., Beutler, E., \& Alving, A.S. (1954) The hemolytic effect of primaquine. II. The natural course of the hemolytic anemia and the mechanism of its selflimited character. J. Lab. clin. Med. 44, 171.

DINE, M.S. (1954) Hyperbilirubinaemia in the newborn premature infant. Amer. J. dis. Child. 88, 810.

Doxiadis, S.A., Fessas, Ph. \& Valaes, T. (1960) Erythrocyte enzyme deficiency in unexplained kernicterus. Lancet, ii, 44

Doxiadis, S.A., Fessas, Ph., Valaes, T. \& Mastrokalos, N. (1961) Glucose-6-phosphate dehydrogenase deficiency. A new aetiological factor of severe neonatal jaundice. Lancet, i, 297.

Doxiadis, S.A., Valaes, T., Karaklis, A. \& Stavrakakis, D. (1964) Risk of severe jaundice in glucose-6-phosphate dehydrogenase deficiency of the newborn. Differences in population groups. Lancet, ii, 1210.

Doxiadis, S.A. \& VAlAes, T. (1964) The clinical picture of glucose-6-phosphate dehydrogenase deficiency in early infancy. Arch. Dis. Childh. 39, 208.

Durton, G.J. (1958) Glucuronide synthesis in foetal liver and kidney. Lancet, 11, 49.

Dutron, G.J. (1959) Glucuronide synthesis in foetal liver and other tissues. Biochem. J. 71, 141.

EshaghPour, E., Oski, F.A. \& Williams, M. (1967) The relationship of erythrocyte glucose-6-phosphate dehydrogenase deficiency in hyperbilirubinaemia in Negro premature infants. J. Pediat. 70, 595.

Fairbanks, V.F. \& Beutler, E. (1962) A simple method for detection of erythrocyte glucose-6-phosphate dehydrogenase (G-6-PD spot test). Blood, 20, 591.

Fessas, Ph., Doxiadis, S.A. \& Valaes, T. (1962) Neonatal jaundice in glucose-6-phosphate dehydrogenase deficient infants. Brit. med. J. ii, 1359.

Flatz, G., Sringam, S., Premyathin, C., Penbharkkul, S. Ketusingh, R. \& Chulazata, R. (1963) Glucose-6phosphate dehydrogenase deficiency and neonatal jaundice. Arch. Dis. Childh. 38, 566.

Flatz, G., Thanangkul, O., Simarak, S. \& Manniaitci, M. (1964) Glucose-6-phosphate dehydrogenase deficiency and jaundice in newborn infants in northern Thailand. Ann. Paediat. 203, 39.

Freier, S., Mayer, K., Levene, C. \& Abrahamov, A. (1965) Neonatal jaundice associated with familial G-6-PD deficiency in Israel. Arch. Dis. Childh. 40, 280.

Garby, L., Suolin, S. \& Viulle, S.C. (1964) Studies on the erythrokinetics of infancy. V. estimations of the life-span of red cells in the newborn. Acta paediat. scand. 53, 165.

Gartner, L. M. \& ARIAS, I.M. (1964) Production of unconjugated hyperbilirubinaemia in full-term newborn infants following administration of pregnance-3 (alpha)-20 (beta) diol. J. Pediat. 65, 1045.

GARTNER, L. \& ARIAS, I.M. (1966) Studies of prolonged neonatal jaundice in the breast-fed infant. J. Pediat. 68, 54.

GASSER, C. (1953) Die hämolytische Fruhgeburten anämie mit spontaner Innerkörperbildung. Helv. Paediat. Acta, 8, 491.

George, J.N., Sears, D.A., McCurdy, P.R. \& Conrad, M.E. (1967) Primaquine sensitivity in Caucasians: Hemolytic reactions induced by primaquine in G-6-PD deficient subjects. J. Lab. clin. Med. 70, 80.

Gray, C.H., Neuberger, A. \& SNeath, P.H.A. (1950) Incorporation of $\mathrm{N}^{15}$ in the normal and the porphyric. Biochem. J. 47, 87.

GreenberG, L.H. \& TANAKA, K.R. (1965) Hereditary Hemolytic anemia due to glucose-6-phosphate dehydrogenase deficiency. Amer. J. dis. Child. 110, 206.

GrodsKy, G. (1967) Studies in the uptake and Intrahepatic transport of $\mathrm{H}^{3}$ bilirubin. Bilirubin Metabolism (Ed. by I.A.D. Bouchier and B.H. Billing). Blackwell Scientific Publications, Oxford.

Grodsky, G.M. \& CARbone, J.V. (1957) The synthesis of bilirubin glucuronides by tissue homogenates. J. biol. Chem. 226, 449.

Grodsky, G.M., Contopoulos, A.N., Fouska, R. \& Carbone, J.V. (1963) Distribution of bilirubin $\mathrm{H}^{3}$ in fetal and maternal rat. Amer. J. Physiol. 204, 837.

Gross, R.T., Bracci, R., RUdolPh, N., Schroeder, E. \& KocHeN, J.A. (1967) Hydrogen peroxide toxicity and detoxification in the erythrocytes of newborn infants. Blood, 29, 481.

Gross, R.T., Schroeder, E.A.R. \& Brounstein S.A. (1963) Energy metabolism in the erythrocytes of premature infants compared to full term newborn infants and adults. Blood, 21, 755.

de Gruchy, G.C., Santamaria, J.N., Parsons, I.C. \& Crawford, H. (1960) Nonspherocytic Congenital Hemolytic anemia. Blood, 16, 1371.

HARLEY, J.D. \& ROBIN, H. (1962) Late neonatal jaundice in infants with glucose-6-phosphate dehydrogenase deficient erythrocytes. Aust. Ann. Med. 11, 148.

HARLEY, J.D. \& RoBIN, H. (1963) Glucose-6-phosphate dehydrogenase deficiency: Pre-natal and post-natal implications. Med. J. Aust. 1, 198.

HARRIS, J.W. (1963) The Red Cell: Production, Metabolism, Destruction Normal and Abnormal. Harvard, Cambridge, Massachusetts.

HeNDRICKSE, R.G. (1965) Discussion Abnormal Haemoglobins in Africa (Ed. by J.H.P. Jonxis), p. 208. Blackwell Scientific Publications, Oxford.

HoffMAN, J.F. (1966) The red cell membrane and the transport of sodium and potassium. Amer. J. Med. 41, 666.

Holland, P., Paglia, D.E., Baugham, M.A. \& Valentine, W.N. (1968) Congenital nonspherocytic anemia with glucosephosphate isomerase deficiency. Program 38th meeting S.P.R.

HolmaN, G.H. (1958) Physiologic hyperbilirubinaemia of premature infants. Pediatrics, 22, 1115.

Hsia, D.Y.Y., Allen, F.H., JR, Gellis, S.S. \& Diamond, L.K. (1953) Serum bilirubin levels in the newborn infant. J. Pediat. 42, 277.

Hsia, D.Y.Y., Dowben, R.M., Show, R. \& Grossman, A. (1960) The inhibition of glucuronosyl transferase by progestational agents from pregnant serum Amer. J. dis. Child. 100, 599.

IfEKWUNIGWE, A.E. \& LuzzatTo, L. (1966) Kernicterus in G-6-PD deficiency. Lancet, i, 667. 
InSCOE, J. \& AXerold, J. (1960) Some factors influencing glucuronide formation in vitro. J. Pharmac. exp. Ther. 129, 128.

JANDL, J.H. (1966) The pathophysiology of hemolytic anemias. Amer. J. Med. 41, 557.

JIM, R.T.S. \& CHU, F.K. (1963) Hyperbilirubinemia due to glucose-6-phosphate dehydrogenase deficiency in a newborn Chinese infant. Pediatrics, 31, 1046.

Justice, P., Ling-Yu Shih, Gordon, J., Grossman, A. \& HsIA, D.Y.Y. (1966) Characterization of leukocyte glucose6-phosphate dehydrogenase in normal and mutant subjects. J. Lab. clin. Med. 68, 552.

KaPlan, E. \& HsU, K.J. (1961) Determination of erythrocyte survival in newborn infants by means of $\mathrm{Cr}^{51}$ labelled erythrocytes. Pediatrics, 27, 354.

Kato, R., Loeb, L. \& Gelboin, H.V. (1965) Increased sensitivity of microsomes from phenobarbital treated rats to synthetic messamger RNA (Polyuridylic acid). Lack of effect on ribosomes. Nature (Lond.), 205, 668.

KATZ, H.P. \& RoBinson, T.A. (1965) Breast-milk hyperbilirubinemia. Report of a case. New Engl. J. Med. 273, 546.

KeITT, A.S. (1966) Pyruvate kinase deficiency and related disorders of red cell glycolysis. Amer. J. Med. 41, 762.

Kellermeyer, R.W., Tarlov, A.R., Schrier, S.H., Carson, P.E. \& Alving, A.J. (1961) The hemolytic effect of primaquine. XIII. Gradient susceptibility to hemolysis of primaquine sensitive erythrocytes. J. Lab. clin. Med. 58, 225.

Khanna, N.N., Stern, L., Levy, G. \& Yaffe, J.S. (1968). Effect of phenobarbital on neonatal hyperbilirubinemia. Program 38th meeting. S.P.R.

KIRKMAN, H.N. (1962) Glucose 6-phosphate dehydrogenase from human erythrocytes. I. Further purification and characterization. J. biol. Chem. 237, 2364.

Kirkman, H.N., Doxiadis, S.A., Valaes, T., Tassopoulos, N. \& Brinson, A.G. (1965) Diverse characteristics of glucose-6-phosphate dehydrogenase from Greek children. J. Lab. clin. Med. 65, 212.

Kirkman, H.N. \& Hendrickson, E.M. (1963) Sex-linked electrophoretic difference in glucose-6-phosphate dehydrogenase. Amer. J. hum. Genet. 15, 241.

Kirkman, H.N., Kidson, CH. \& KenNedy, M. (1968) Variants of human glucose-6-phosphate dehydrogenase. Studies of samples from New Guinea. Hereditary Disorders of Erythrocyte Metabolism. Grune \& Stratton, New York.

Kirkman, H.N., Riley, H.D. \& Crowell, B.B. (1960) Different enzymic expressions of mutants of human glucose-6-phosphate dehydrogenase. Proc. nat. Acad. Sci. (Wash.), 46, 938.

KirkmaN, H.N. \& Riley, H.D. JR, (1961) Congenital nonspherocytic hemolytic anemia. Amer. J. dis. Childh. $102,313$.

Kirkman, H.N., Rosenthal, I.M., Siman, E.R., Carson, P.E. \& BRINSON, A.G. (1964b) Chicago I. variant of glucose-6-phosphate dehydrogenase in congenital hemolytic disease. J. Lab. clin. Med. 63, 715.

Kirkman, H.N., Schettini, F. \& Pickard, B.M. (1964a) Mediterranean variant of glucose-6-phosphate dehydrogenase. J. Lab. clin. Med. 63, 276.

KRASNER, J. \& YAFFE, S.J. (1968) Changes in bilirubin UDPGlucuronyl transferase during postnatal development. Program 38th meeting S.P.R.

Lathe, G.H., Claireaux, A.E. \& Norman, A.P. (1958) Jaundice in the newborn infant. I. Non-obstructive jaundice. Recent Advances in Pediatrics. Churchill, London.

Lathe, G.H. \& Walker, M. (1957) An enzymatic defect in human neonatal jaundice and in Gunn's strain of jaundiced rats. Biochem. J. 67, 9.

LATHE, G.H. \& WALKER, M. (1958). The inhibitory effect of human pregnancy serum, neonatal serum and steroids on the conjugation of bilirubin by rat-liver slices. Biochem. J. 68,6 .
LAWRENCE, B. (1955) Danger of vitamin K. analogues to newborn. Lancet, i, 819.

Lausecker, Ch., Heidt, P., Fisher, D., Hartleyb, H. \& § LöHR, G.W. (1965) Anémie hémolytique constitutionelle $c$ avec déficit en 6-phospho-gluconate-dehydrogenase. Un nouveau type d'anémie avec carence enzymatique intra- $\sigma$ erythrocytaire. Arch. franc. Pédiat. 22, 789.

Lee, C., Tink, A., Robin, M. \& Hari.ey, J. (1961) Neonatal jaundice. Two cases associated with G-6-PD deficiency in erythrocytes. Med. J. Aust. 2, 315.

Lelong, M., Alagille, D. \& Odievre, M. (1964) Les anomalies hémolytiques du nouveau-né à l'exception des incompatibilités sanguines. Nouv. Rev. franc. Hémat. 4, 110. ¿

LESTER, R., BeHRMAN, R.E. \& LUCEY, J.F. (1963) Transfer of bilirubin C-14 across monkey placenta. Pediatrics, 32, 416.

LeSTER, R. \& SCHMID, R. (1964) Bilirubin metabolism. New Engl. J. Med. 270, 779.

Levin, S.E., Charlton, R.W. \& Freiman, J. (1964) Glucose6-phosphate dehydrogenase deficiency and neonatal jaundice in South African Bantu infants. J. Pediat. 65, 757.

LöHR, G.W. \& WALLER, H.D. (1962) Eine neue enzymopenische hämolytische Anämie mit Glutathioreduktasemangel. Med. Klin. 57, 1521.

LöHR, W.E. \& WALLER, H.D. (1963) Zur biochemie einiger angeborener Hämolytischer anämien. Folia Haemat. Neue Folge, $8,1$.

London, I.M., West, R., Shemin, D.E. \& Rittenberg, D. (1950) On the origin of bile pigment in normal man. J. biol. Chem. 184, 351.

Lu, T.C., Lee, T.C. \& Chen, C.L. (1963) Studies of serum bilirubin levels and its fractions in the Chinese newborn infants. Acta Paediat. Sinica, 4, 1 .

LU, T.C, WEI, H. \& BlaCKWEll, R.Q. (1966) Increased incidence of severe hyperbilirubinemia among newborg Chinese infants with G-6-PD deficiency. Pediatrics, 37, 994

LUNDER, D. \& GARTLER, S.M. (1965) Distribution glucose-6-phosphate dehydrogenase electrophorectic vart ants in different tissues of heterozygotes. Amer. J. hum. Genet. 17, 212.

LuCEY, J. F. (1960) Hyperbilirubinaemia of prematurity. Pediatrics, 25, 690 .

LUCEY, J.F. \& Dolan, R.G. (1959) Hyperbilirubinaemia of newborn infants associated with the parenteral administra- $\overline{\bar{O}}$ tion of a vitamin $\mathrm{K}$ analogue to the mothers. Pediatrics, 23, 553 .

Lucey, J.F., Phillips, C. \& McKay, R.J. (1960) A difference in the incidence of hyperbilirubinaemia among premature infants in two hospitals. Amer. J. dis. Childh. 100, 791.

Maisels, M.J., Pathak, A. \& Nelson, N.M. (1968) Endogenous production of carbon monoxide in normal and erythroblastic infants. Clin. Res. 16, 538.

MARKS, P. (1963) G6PD deficiency in different population groups. The Genetics of Migrant and Isolate Populations (Ed. by E. Goldschmidt), p. 75. Williams \& Wilkins, Baltimore.

Marks, P.A., Johnson, A.B. \& HirschberG, E. (1958). Effect of age on the enzyme activity in erythrocytes. Proc. I nat. Acad. Sc. (Wash.), 44, 529.

Marks, P.A., SzeinberG, A. \& Banks, J. (1961) Erythrocyte glucose-6-phosphate dehydrogenase of normal and $\sigma$ mutant human subjects: properties of the purified enzyme. J. biol. Chem. 236, 10.

Mather, A. (1960) Reliability of bilirubin determinations in icterus of the newborn infant. Pediatrics, 26, 350.

Maurer, H.A., Wolf, J.A., Finster, M., Poppers, P J., Pantuck, E. \& Kuntzman, R. (1968) Reduction in concentration of total serum bilirubin in offspring of women treated with phenobarbital during pregnancy. Lancet, i, ? 122.

Meyer, T.C. \& ANgus, J. (1956) The effect of large doses of synkavit in the newborn. Arch. Dis. Childh. 31, 212. 
Miller, D.R., Paglia, D.E., Valentine, W.N., Baugham, M.A., ReED, C.F. \& MCINTYRE, D.R. (1968) An inherited kinetically aberrant isozyme of erythrocyte pyruvate kinase (PK) responsible for hereditary hemolytic anemia. Program 38th meeting S.P.R.

MotUlSKY, A.G. (1960) Metabolic metamorphisms and the role of infectious diseases in human evolution. Human Biol. 32, 28.

MotUlSKY, A.G. (1963) Theoretical and clinical problems of glucose 6-phosphate dehydrogenase deficiency: its occurrence in Africans and its combination with hemoglobinopathy. Proc. 2nd Symposium on Abnormal Haemoglobins, sponsored by C.I.O.M.S. Ibadan, Nigeria.

Motulsky, A.G. (1964) Hereditary red cell traits and malaria. Amer. J. trop. med. 13, 147.

MotulsKY, A.G. \& CAMPBELL-KRAUT, J.M.(1961) Population genetics of glucose-6-phosphate dehydrogenase deficiency of the red cell. Proc. Conf. Genetic Polymorphisms and Geographic Variations in Diseases, p. 159. Grune \& Stratton, New York.

Motulsky, A.G. \& Stamatoyannopoulos, G. (1966) Clinical implications of glucose-6-phosphate dehydrogenase deficiency. Ann. intern. Med. 65, 1329.

Naiman, J.L. \& Kosoy, M.H. (1964) Red cell glucose-6-phosphate dehydrogenase deficiency-a newly recognized cause of neonatal jaundice and Kernicterus in Canada. Can. med. Ass. J. 91, 1243.

Necheles T.F., Boles, T.A. \& Allen, D.M. (1968) Erythrocyte glutathione-peroxidase deficiency and hemolytic disease of the newborn infant. J. Pediat. 72, 319.

Newmann, A.S. \& Gross, S. (1963) Hyperbilirubinemia in breast fed infants. Pediatrics, 32, 995.

Newton, W.A., JR \& BASS, J.C. (1958) Glutathione sensitive chronic non-spherocytic hemolytic anemia. Amer.J. dis. Child. 96, 501.

Newton, W.A., JR \& Frajola, W.J. (1958) Drug-sensitive chronic hemolytic anemia: family studies. Clin. Res. 6, 392.

Nitowsky, H.M., Davidson, R.C., Soderman, D.D. \& ChILDS, B. (1965) Glucose-6-phosphate Dehydrogenase activity of skin fibroblast cultures from enzyme deficient subjects. Bull. Johns Hopk. Hosp. 117, 363.

Obrinsky, W., Allen, E.L. \& Anderson, E.E. (1954) Physiologic hyperbilirubinemia in premature infants. Amer. J. dis. Child, 87, 305.

O'FlYNN, M.E.D. \& Hsia, D.Y.Y. (1963) Serum bilirubin levels and glucose-6-phosphate dehydrogenase deficiency in new-born American Negroes. J. Pediat. 63, 160.

OorT, M., Loos, J.A. \& PrINS, H.K. (1961) Hereditary absence of reduced glutathione in the erythrocytes-a new clinical and biochemical entity? Vox Sang. (Basel), 6, 370.

OsKI, F.A. (1965) The metabolism of erythrocytes, and its relation to hemolytic anemia in the newborn. Pediat. Clin. N.Amer. 12, 687.

OsKI, F. (1967) Red cell metabolism in the premature infant. II. The pentose phosphate pathway. Pediatrics, 39, 689.

OsKI, F.A. \& DiAmoND, L.K. (1963) Erythrocyte pyruvate kinase deficiency resulting in congenital nonspherocytic hemolytic anemia. New Engl. J. Med. 269, 763.

Oski, F.A., EshaghPour, E. \& Williams, M.L. (1966) Red cell glucose-6-phosphate dehydrogenase deficiency as a cause of hyperbilirubinaemia in the premature infant. J. Pediat. 69, 903.

Oski, F.A. \& Naiman, J.L. (1965) Red cell metabolism in the premature infant. Pediatrics, 36, 104.

OsKi, F.A., Nathan, D.G., Sidel, V.W. \& Diamond, L.K. (1964) Extreme hemolysis and red-cell distraction in erythrocyte pyruvate kinase deficiency. I. Morphology erythrokinetics and family enzyme studies. New Engl. J. Med. 270, 1023.

Paglia D.E., Valentine, W.N., Bingham, M.A., Miller, D.R., REED, C.F. \& MCINTYRE, D.R. (1967) Identification of an isozyme of erythrocyte pyruvate kinase (PK) responsible for hereditary hemolytic anemia. Blood, 30,881 .

Panizon, F. (1960a) Erythrocyte enzyme deficiency in unexplained kernicterus. Lancet, ii, 1093.

Panizon, F. (1960b) L'ictère grave du nouveau-né associé à une deficience en glucose-6-phosphate déhydrogenase. Biol. neonat. 2, 167.

Pearson, H.A. (1967) Life-span of the fetal red blood cell. J. Pediat. 70, 166.

Pinto, P.V.C., Newton, W.A., JR \& Richardson, K.E. (1966) Evidence for four types of erythrocyte glucose-6phosphate dehydrogenase from G-6-PD deficient human subjects. J. clin. Invest. 45, 823.

Piomelli, S., Amorosi, E., Miraglia, J. \& Richter, J. (1968) Defective G6PD synthesis in chronic non-spherocytic hemolytic anemia. 38th meeting S.P.R.

Prankerd, T.A.J. (1961) The Red Cell. An Account of its Chemical Physiology and Pathology. Blackwell Scientific Publications. Oxford.

Prankerd, T.A.J. (1965) Clinical significance of red-cell structure and metabolism. Brit. med. J. ii, 1017.

Prins, H.K., Loos, J.A. \& ZürCHER, C. (1968) Glutathione deficiency. Hereditary Disorders of Erythrocyte Metabolism (Ed. by E. Beutler). Grune \& Stratton, New York.

Prins, H.K., OORT, M., LoOs, J.A., ZuZCher, C. \& Beckers, T. (1966) Congenital nonspherocytic hemolytic anemia associated with glutathione deficiency of the erythrocytes. Blood, 27, 145.

RöstA, J. \& Szöke, L. (1965) Prolonged icterus neonatorum of breast fed infants. Acta Paediat. Hung. 6, 221.

SACHS, J.R., WiCKer, D.J., GilChER, R.O., CoNRAD, M.E. \& CoHen, A.S. (1967) PK deficient hemolytic anemia inherited as an autosomal dominant. Blood, 30, 881 .

Salvidio, E., Pannacciuli, I., Tizianello, A. \& AJMar, F. (1967) Nature of hemolytic crises and the fate of G-6-PD deficient damaged erythrocytes in Sardinians. New Engl. J. Med. 276, 1339.

Say, B., Ozand, P., Berkel, I. \& Cevik, N. (1965) Erythrocyte glucose-6-phosphate dehydrogenase deficiency in Turkey. Acta paediat. scand. 54, 319.

SCHENKer, S., Bushare, R.A. \& SMITH, F. (1967) Bilirubin disposition in foetal monkeys. Bilirubin Metabolism (Ed. by J.A.D. Bouchier and B.H. Billing). Blackwell Scientific Publications, Oxford.

SCHENKER, S., DAWBER, N.H. \& SCHMID, R. (1964) Bilirubin metabolism in fetus. J. clin. Invest. $43,32 \mathrm{e}$.

Schettini, F., Meloni, T., Corda, G. \& Mela C. (1963) Red cell survival in jaundiced newborn children with erythrocyte enzyme deficiency. Lancet, ii, 1012.

SCHMid, R., Hammaker, L. \& Axelrod, J. (1957) The enzymatic formation of bilirubin glucuronide. Arch. Biochem. 70, 285.

Schnieder, A.S., Valentine, W.N., Baughan, M.A., Paglia, D.E., Shore, N.A. \& Heins, H.L. (1968) Triosephosphate isomerase deficiency. Hereditary Disorders of Erythrocyte Metabolism (Ed. by E. Beutler). Grune \& Stratton, New York.

SChneider, A.S., Valentine, W.N., Hattori, M. \& Heins, H.L. (1965) Hereditary hemolytic anemia with triosephosphate isomerase deficiency. New Engl. J. Med. 272, 229.

SCHRÖTER, W. (1965) Kongenitale michtsphärocytäre hämolytische Anämie bei 2-3 diphosphoglyceratmutaseMangel der Erythrocyten in frülen Sänglangsalter. Klin. Wschr. 43, 1147.

Scialom, C., Najean Y. \& Bernard, J. (1966) Anémie hémolytique congénitale non-spherocytaire avec déficit incomplet en 6-phosphogluconate dehydrogenase. Nouv. Rev. franc. Hemat. 6, 452.

Sereni, F. \& Principi, N. (1965) The development of enzyme systems. Pediat. Clin. N. Amer. 12, 515. 
Shahidi, N.T. \& DiAmond, L.K. (1959) Enzyme deficency in erythrocytes in congenital nonspherocytic hemolytic anemia. Pediatrics, 24, 245.

Shore, N.A., Schneider, A.S. \& Valentine, W.N. (1965) Erythrocyte triosephosphate isomerase deficiency. $J$. Pediat. 67, 939.

Smith, G. \& Vella, F. (1960) Erythrocyte enzyme deficiency in unexplained kernicterus. Lancet, $\mathbf{i}, 1133$.

Stiehm, E.R. \& Ryan, J. (1965) Breast milk jaundice. Amer. J. dis. Child. 109, 212.

Szeinberg, A., Oliver, M., Schmidt, R., AdAm, A. \& SHEBA, C. (1963) Glucose-6-phosphate dehydrogenase deficiency and haemolytic disease of the newborn in Israel. Arch. Dis. Childh. 38, 23.

Tanaka, K.R., VAlentine, W.N. \& MiWA, S. (1962) Pyruvate kinase deficiency hereditary nonspherocytic hemolytic anemia. Blood, 19, 267.

TADA, K. (1961) Enzymatic anomaly of erythrocytes in congenital nonspherocytic hemolytic anemia. Tohoku J. exp. Med. 75, 263.

Trolle, D. (1968) Phenobarbitone and neonatal icterus. Lancet, $\mathrm{i}, 251$.

VAlaes, T. (1961) Red cell enzymes and severe neonatal jaundice. Cerebral Palsy Bull. 3, 431.

Valaes, T. (1963) Bilirubin distribution and dynamics of bilirubin removal by exchange transfusion. Acta paediat. scand. 52 Suppl., 149.

Valaes, T., Doxiadis, S.A. \& Fessas, Ph. (1963) Acute hemolysis due to naphthalene inhalation. J. Pediat. 63,904.

Valaes, T. \& Doxiadis, S.A. (1967) Anaemia and icterus in the neonate from haemorrhage in the soft tissues of the skull. Acta Soc. Paediat. Hellenicae, 30, 414.

Valaes, T., Fessas, Ph. \& Doxiadis, S.A. (1961) Kernicterus in full term infants without isoimmunisation. Proc. R.Soc.Med. 54, 331.

VAlaEs, T. \& KARAKLIS, A. (1967) Relation of severe jaundice from G-6-PD deficiency to the general pattern of neonatal hyperbilirubinaemia in the population. Program IX Meeting European Club Pediatric Res., Copenhagen.

Valaes, T., Karaklis, A., Stavrakakis, D., BavelaStavrakakis, K., Perakis, A. \& Doxiadis, S.A. (1968) Incidence and mechanism of neonatal jaundice related to G-6-PD deficiency. (For publication.)

VAlentine, W.N., Oski, F.A., Paglia, D.E., Baughan, M.A., SCHNEIDER, A.S. \& NaImAN, J.L. (1967) Hereditary hemolytic anemia with hexokinase deficiency. Role of hexokinase in erythrocyte aging. New Engl. J.Med. 276,1.

VAlentine, W.N., Schneider, A.S., BaughaM, M.A., PAGlia, D.E. \& HeInz, H.L. (1966) Hereditary hemolytic anemia with triosephosphate isomerase deficiency. Amer. J. Med. 41, 27.

VEST, M. (1958) Insufficient glucuronide formation in the newborn and its relationship to the pathogenesis of icterus neonatorum. Arch. Dis. Childh. 33, 473.

VEST, M.F. (1967) Studies on haemoglobin breakdown and incorporation of [I5N] glycine into haem and bile pigment in the newborn. Bilirubin Metabolism (Ed. by I.A.D. Bouchier and B.H. Billing). Blackwell Scientific Publications, Oxford

VEST, M.F. \& GRIEDER, H.R. (1961) Erythrocyte survival in the newborn infant, as measured by chromium 51 and its relation to the postnatal serum bilirubin level. J. Pediat. 59, 194.

VolPato, S., Vigi, V. \& Cattarozi, G. (1968) Non spherocytic haemolytic anaemia \& severe jaundice in a newborn with partial pyruvate kinase deficiency. Acta paediat. scand. 57, 59.

WALLER, H.D. \& GeroK, W. (1964) Schwere strahlemnduzierte Hämolyse bei hereditären Mangel an reduziertem Glutathion in Blutzellen. Klin. Wschr. 42, 948.

Waller, H.D., KaufmanN, W., Gerok, W. \& Eggstein, M. (1964) Biochemische Befunde bei heterozygoten
Glutathionreduktasemangel trägerinnen mit Pilzvergiftung Klin Wschr. 42, 613.

Waller H.D., Lohr, G.W., Zysno E., Gerok, W., Voss, D. \& Strauss G. (1965) Glutathionreduktasemangel mit hämatologischen und neurologischen störungen Klin. Wschr. 43, 8; 413 .

Waters, W.J., Dunham, R. \& Bowen, W.R. (1968) Inhibition of bilirubin conjugation in vitro. Proc. Soc. exp. Biol. (N.Y.), 99, 175.

Weatherall, D.J. (1960) Enzyme deficiency in haemolytic disease of the newborn. Lancet, ii, 835.

Weber, W.W. \& CoHeN, S.N. (1968) Drug conjugating enzymes in the newborn: Kinetic studies of $\mathrm{N}$-AcetylTransferase in the infant rabbit. Program 38th meeting S.P.R.

Westphal. M., Viergiver, E. \& Roth, R. (1962) Analysis of a bilirubin survey. Pediatrics, 30, 12.

WolfF, J.A., Grossman, B.H. \& PAYA, K. (1967) Neonatal serum bilirubin and glucose-6-phosphate dehydrogenase. Amer. J. dis. Child. 113, 251.

WoNG, H.B. (1964) Neonatal hyperbilirubinemia. Bull. Kandag. Kerban Hosp. Singapore, 3, 1.

WoNG, H.B. (1966) Singapore kernicterus: a review and the present position. Kandang Kerban Hosp. Singapore, 5, 2.

WYNN, R.M. (1963) The placental transfer of bilirubin. Amer. J. Obst. Gynec. 86, 841.

Yaffe, S.S., Levy, G., Matsuzawa, T. \& Baliah, T. (1966) Enhancement of glucuronide conjugating capacity in a hyperbilirubinemic infant due to apparent enzyme induction by phenobarbital. New Engl. J. Med. 275, 1461.

Yoshida, A. (1966) Glucose-6-Phosphate dehydrogenase of human erythrocytes. I. Purification and characterization of normal (B) enzyme. J. biol. Chem. 241, 4966.

YoshidA, A. (1968) The structure of normal and variand human glucose-6-phosphate dehydrogenase. Hereditar Disorders of Erythrocyte Metabolism (Ed. by E. Beutler) Grune \& Stratton, New York.

Yoshida, A., Stamatoyannopoulos, G. \& Motulsky, A. (1967) Negro variant of glucose-6-phosphate dehydrogenase deficiency (A-) in man. Science, $155,97$.

Yoshida, A., Stamatoyannopoulos, G. \& Motulsky, A.G. (1968). Biochemical genetics of glucose-6-phosphate dehydrogenase variation. Ann. N.Y. Acad. Sci. (In press).

YUe, P.C.K. \& STRICKLAND, M. (1965) Glucose-6-phosphate dehydrogenase deficiency and neonatal jaundice in Chinese male infants in Hong Kong. Lancet, $1,350$.

Zannos-Mariolea, L., Thomaidis, Th., Georgizas, G. GaVRIELIDOU, E. \& Benetos, S. (1968) Diagnostic problems in severe neonatal jaundice and G-6-PD deficiency in Greece. Arch. Dis. Childh. 43, 36

ZaRkoWSKY, H.S., LAFORET, M.T., MenTZER, W.C. \& NATHAN, D.G. (1968) Lack of correlation of PK activity with metabolic dysfunction. Program 38th meeting S.P.R.

ZINKHAM, W.H. (1959) An in vitro abnormality of glutathione metabolism in erythrocytes from normal newborns mechanism and clinical significance. Pediatrics, 23, 18.

ZINkHaM, W.H. (1963) Peripheral blood and bilirubin values in normal full-term primaquine-sensitive Negro infants effect of vitamin K. Pediatrics. 31, 983.

ZinkHAM, W.H. \& CHILDS, B. (1957) Effect of naphthalene derivatives on glutathione metabolism of erythrocytes from patients with naphthalene hemolytic anemia. J. clin. Invest. 36, 938 .

Zinkham, W.H. \& Childs, B. (1958) A defect in GSH metabolism in erythrocytes from patients with a naphthalene-induced hemolytic anemia. Pediatrics, 22, 461.

Zinkham, W.H. \& LenhaRd, R.E. (1959) Metabolic abnormalities of erythrocytes from patients with congenital nonspherocytic hemolytic anemia. J. Pediat. 55, 319.

ZUELZER, W.W. \& BROWN, A.K. (1961) Neonatal jaundice, a review. Amer. J. dis. Child. 101, 87. 